\title{
The PELGAS survey: ship-based integrated monitoring of the Bay of Biscay pelagic ecosystem
}

\author{
Doray Mathieu ${ }^{1,}{ }^{*}$, Petitgas Pierre ${ }^{1}$, Romagnan Jean-Baptiste ${ }^{1}$, Huret Martin ${ }^{2}$, Duhamel Erwan ${ }^{3}$, \\ Dupuy Christine ${ }^{4}$, Spitz Jérome ${ }^{5}$, Authier Matthieu ${ }^{5}$, Sanchez Florence ${ }^{7}$, Berger Laurent ${ }^{7}$, \\ Dorémus Ghislain ${ }^{5}$, Bourriau Paul ${ }^{1}$, Grellier Patrick ${ }^{1}$, Massé Jacques ${ }^{1}$
}

${ }^{1}$ Unité Écologie et Modèles pour l'Halieutique, Ifremer Nantes, Rue de l'lle d'Yeu, BP 21105, 44300

Nantes Cedex 3, France

${ }^{2}$ Laboratoire de Biologie Halieutique, Centre Ifremer Bretagne - ZI de la Pointe du Diable - CS 10070 29280 Plouzané

${ }^{3}$ Laboratoire de Technologie et Biologie Halieutique, Station Ifremer de Lorient - 8, rue François Toullec

- 56100 Lorient

${ }^{4}$ Université de la Rochelle-CNRS, UMR 7266, Littoral Environnement et Sociétés (LIENSs), 2 rue

Olympe de Gouges, 17000 La Rochelle cedex, France

${ }^{5}$ Observatoire PELAGIS, UMS 3462, Université de La Rochelle/CNRS, La Rochelle, France

${ }^{6}$ Laboratoire Environnement Ressources d'Arcachon. Station Ifremer d'Anglet. UFR Côte Basque - 1,

allée du Parc Montaury - 64600 Anglet, France

${ }^{7}$ Service Acoustique Sous-marine et Traitement de I'Information, Centre Ifremer Bretagne - ZI de la

Pointe du Diable - CS 10070 - 29280 Plouzané, France

* Corresponding author : Mathieu Doray, email address : $\underline{\text { mathieu.doray@ifremer.fr }}$

\begin{abstract}
:
The Pélagiques Gascogne (PELGAS) integrated survey has been developed by a multidisciplinary team of Ifremer and La Rochelle University scientists since 2000 , joined by commercial fishermen in 2007. Its initial focus was to assess the biomass and predict the recruitment success of anchovy in the Bay of Biscay in spring. Taking advantage of the space and versatility of R/V Thalassa II, sampling has been progressively extended to other ecosystem components. PELGAS therefore further developed the second objective of monitoring and studying the dynamic and diverse Biscay pelagic ecosystem in springtime. The PELGAS survey model has allowed for the establishment of a long-term time-series of spatially-explicit data of the Bay of Biscay pelagic ecosystem since the year 2000. Main sampled components of the targeted ecosystem are: hydrology, phytoplankton, mesozooplankton, fish and megafauna. The survey now provides two main ecosystem products: standard raster maps of ecosystem parameters, and a time series dataset of indicators of the Bay of Biscay pelagic ecosystem state. They are used to inform fish stock and ecosystem-based management, and support ecosystem research. The present paper introduces the PELGAS survey, as a practical example of an integrated, vessel-based, ecosystem survey. The evolution of the PELGAS scientific team and sampling protocols are presented and analysed, to outline factors crucial to the success of the survey. Data and results derived from PELGAS are reviewed, to exemplify scientific questions that can be tackled by integrated ecosystem survey data. Advantages and challenges of the survey are discussed and put into the context of marine ecosystem surveys in the European Marine Strategy Framework Directive and the
\end{abstract}


Common Fisheries Policy.

\section{Highlights}

- The PELGAS integrated survey conducted since 2000 in spring in the Bay of Biscay is presented.

PELGAS objectives have switched from the study of the anchovy stock status to ecosystem monitoring. - Spatially-explicit data have been collected of the main pelagic ecosystem components since 2000. Multidisciplinary collaborative working and enough vessel space were critical success factors. Finding relevant common scales is essential to analyse ecosystem data within or across compartments.

Keywords : Pelagic ecosystem, Integrated ecosystem monitoring survey, Marine Strategy Framework Directive, Ecosystem variability, Bay of Biscay, Fishing vessels 


\section{Introduction}

The Pélagiques Gascogne (PELGAS, Doray et al., 2000) survey monitors the Bay of Biscay pelagic ecosystem in springtime. The main goal of PELGAS is to provide information for a management plan in accordance with an ecosystem approach to fisheries (EAF; Garcia et al., 2003). As such, PELGAS also aims at studying the structure and dynamics of the pelagic ecosystem on the continental shelf. PELGAS has been conducted by the Institut français de recherche pour l'exploitation de la mer (Ifremer), in collaboration with La Rochelle University and the Centre national de la recherche scientifique (CNRS) since 2000. As for other 
long term, multidisciplinary, ecosystem surveys such as CalCofi (CalCOFI, 2011), Convention on the Conservation of Antarctic Marine Living Resources (CCAMLR) Ecosystem Monitoring Program (Agnew, 1997) or the Barents Sea ecosystem survey (Eriksen, 2014; Eriksen et al., this volume), the initial aim of PELGAS was the provision of scientific information for fisheries management. PELGAS initial objective was to provide springtime biomass estimates of the Bay of Biscay anchovy (Engraulis encrasicolus) population to the ICES stock assessment group WGHANSA in charge of this commercially important species.

The PELGAS survey takes place in a dynamic and biologically diverse pelagic ecosystem, located in a subtropical/boreal transition zone. The Bay of Biscay is an open oceanic bay delimited by the west-east oriented Spanish coast in the southern part, and the north-south oriented French coast in the eastern part (Figure 1). It is part of the subtropical/boreal transition subprovince of the biogeographic Lusitanian province (OSPAR Commission, 2000), where mixing between faunal groups of boreal and subtropical origin occurs. The seasonal southern or northern distribution limits of many fish species populations are contained within the Bay of Biscay (Poulard and Blanchard, 2005). Ambient environmental conditions are variable in springtime in Biscay, depending on the onset and magnitude of post-winter phytoplanktonic blooms, seasonal water warming and stratification setup, coastal upwellings, as well as cumulated intensity of winter river discharge and plume spreading over the shelf (Huret et al., this volume; Koutsikopoulos and Le Cann, 1996).

The diversity and dynamic nature of the Bay of Biscay pelagic ecosystem largely influences anchovy population dynamics (Koutsikopoulos and Le Cann, 1996; Planque et al., 2007). This illustrates well some of the earliest observations in fisheries science, acknowledging the "complex interactions of the (marine) living beings" (Lankester, 1884) and the importance of recruitment in small pelagic fish population dynamics (Hjort, 1914). Based on these findings, PELGAS was designed as an integrated ecosystem survey, requiring extensive sampling of several ecosystem components, working towards an improved understanding of target species population dynamics, in the context of EAF.

This paper introduces PELGAS, as a practical example of an integrated, vessel-based, ecosystem survey. The evolution of the PELGAS scientific team and sampling protocols are presented and analysed, to outline the 
factors critical to the success of the survey. Data and results derived from PELGAS are reviewed, to illustrate some scientific questions that can be tackled by integrated ecosystem survey data. We further discuss advantages and challenges of the survey. In conclusion, integrated ecosystem surveys are assessed in the context of the European Marine Strategy Framework Directive (MSFD, 2008/56/EC).

\section{From target species biomass assessment to multidisciplinary pelagic ecosystem}

\section{monitoring}

Due to advances in research vessel engineering and methodological as well as technological advances in the sampling of small pelagic fish, since the early 1980's, the extensive pelagic ecosystem monitoring during PELGAS has been rendered possible. When it comes to sampling methodology, mainly the development of fisheries acoustics (Simmonds and MacLennan, 2005) and egg-based methods (Daily Egg Production Method, DEPM; Lasker, 1985; Continuous Underway Fish Egg Sampler, CUFES; Checkley Jr et al., 1997) in the late 90's enabled to more accurately estimate the biomass and spatial distribution of small pelagic fish eggs and adults. In France, protocols and software (MOVIES software; Weill et al., 1993) for standardised assessment of small pelagic fish biomass by acoustic methods have continuously been developed by Ifremer since the early eighties. Acoustic-trawl (AT) surveys conducted in the Bay of Biscay aboard R/V Thalassa I from 1989 to 1994 led to the definition of sampling strategies for estimating small pelagic fish abundance (Massé and Retière, 1995). First acoustic biomass estimates of the Bay of Biscay anchovy population were provided to the ad-hoc ICES stock assessment group in 1989.

On the platform side, the commissioning of R/V Thalassa II $^{1}$ in 1996 , a large (73 m long) research vessel, $(\mathrm{R} / \mathrm{V})$ designed by Ifremer for multi-disciplinary research in the fields of fisheries science, biology and oceanography, enabled a whole range of possibilities for a more holistic sampling approach. R/V Thalassa II, a noise reduced stern trawler, provided more space (10 m longer), with the possibility of accommodating large scientific teams and crews (25 people max. each) and multidisciplinary equipment. Available equipment includes diverse echosounders, fishing gears, fully equipped wet and dry biological and oceanography laboratories, instrumented winches for probes and plankton nets, etc. Since the onset of

1 http://flotte.ifremer.fr/fleet/Presentation-of-the-fleet/Vessels/Deep-sea-vessels/Thalassa 
oceanography in the $18^{\text {th }}$ century, vessel space available for scientific purposes has always been a limiting factor when it comes to the development of multidisciplinary scientific studies at sea (Adler, 2014). A major reason of the success of the HMS Challenger voyage (1872-1876), frequently cited as the first oceanographic survey, was the accommodation of shipboard science by redistribution of vessel space (Adler, 2014).

Just like the HMS Challenger contributed substantially to the foundation of the modern oceanographic science, the introduction of R/V Thalassa II aimed at providing the space needed, combined with cutting edge equipment and skilled crew to produce innovative multidisciplinary pelagic ecosystem monitoring. Such monitoring plans have been envisioned by the French research community since the early 90 's. Trial surveys have been conducted by Ifremer in 1997 and 1998 in the Bay of Biscay during springtime aboard the $\mathrm{R} / \mathrm{V}$ Thalassa II, to assess the capabilities of the new vessel and develop protocols for holistic pelagic ecosystem sampling. Researchers from a consortium of French institutes and universities collaborating within EAF-oriented national research programs were invited to participate. This collaboration was a milestone in the standardisation of ecosystem sampling in practice, within the context of the Bay of Biscay. The PELGAS survey was originally designed by this multidisciplinary consortium of scientists with two main objectives: i) routine collection of information on the state of the Bay of Biscay pelagic ecosystem, to inform the European Common Fisheries Policy Data Collection Framework (DCF), and ii) conducting additional ecosystem process studies. The original question raised at the onset of the PELGAS survey was: 'how to understand the Biscay anchovy population dynamics, based on data collected during an annual shipbased survey?'. A priori knowledge about about the strong dependence of the anchovy population dynamics on environmental changes, via recruitment success, led to the design of a sampling protocol that encompassed several ecosystem components, and required multidisciplinary collaboration.

The PELGAS area, timeframe and protocols were defined according to the anchovy life cycle: the sampling scheme covers the Biscay continental shelf in May, where spawning anchovy are known to concentrate in springtime (ICES, 2010). PELGAS fisheries acoustic biomass estimates were based on the acoustic observation of fish schools, in combination with directed biological sampling. Biological sampling was based on fishing activities targeting pelagic schools, aiding accurate species-specific fish acoustic backscatter partitioning. As small pelagic fish schools generally disperse at night (Blaxter and Hunter, 1982; Fréon and 
Misund, 1999), small pelagic fish sampling during night-time was deemed inappropriate for PELGAS. As such, daytime (daylight hours) was denoted as the period for small pelagic fish acoustic or trawl sampling, and other compatible sampling activities. Night-time (hours of darkness) was available for observing other ecosystem components. An example of such a night-time activity would be the hydro-biological sampling at fixed stations, performed by fisheries oceanographers, who joined the fisheries biologists on the same "floating laboratory and observatory" (Adler, 2014). Scientists who could adapt their protocols or questions to those diel sampling constraints continued using PELGAS as a key sampling opportunity. After initial adjustments in 2000 and 2001, PELGAS was established as a multidisciplinary survey, sampling the main pelagic ecosystem components, including small pelagic fish in the Bay of Biscay since 2002. PELGAS shiptime has been funded by Ifremer since 2000 and co-funded by the European (EU) Common Fisheries Policy Data Collection Framework (DCF) since 2001. Those stable sources of funding have so far enabled the long-term integrated monitoring of the Bay of Biscay pelagic ecosystem in spring during the PELGAS survey.

Observations made at the beginning of the survey series revealed that: i) to better characterise bottom up and top down controls with regards to population dynamics of anchovies in the Bay of Biscay, complementary data on other ecosystem-components is required, ii) the use of standard protocols to study anchovy in its biotope could provide knowledge on other species and ecological processes. As in other small pelagic fishrelated long-term surveys (e.g. Calcofi; CalCOFI, 2011), the key objectives of PELGAS have then been adapted. Forthcoming PELGAS became an ecosystem monitoring survey, continuing to provide fisheryindependent fish biomass estimates required for fish stock assessment, whilst monitoring the entire pelagic ecosystem, rather than solely focusing on a single stock of one species. New standardised sampling protocols and process studies implemented over the survey series are summarised in Table 1 and detailed in the next section.

\section{Integrated ecosystem data collection and analysis}

\section{Ecosystem sampling}

Methods used during PELGAS for collecting and processing acoustic, trawling and fish egg data for small 
pelagic fish biomass assessment have been developed and adapted to the Bay of Biscay within the framework of the European project PELASSES, (2000-2002, DGXIV n ${ }^{\circ}$ 99.010). They are currently being reviewed and standardised within a more international context through the ICES WGACEGG working group (ICES, 2016).

PELGAS sampling operations are performed round the clock. The scientific contingent comprises 23 people, split into 4 teams (the acoustic team, the fishing team, the hydrobiology team and the megafauna team). The acoustic team ( $\sim 6$ people) is in charge of the fisheries data collection and pre-processing; the fishing team ( $\sim 6$ people) processes the midwater trawl catches; the hydrobiology team ( $\sim 7$ people) operates a CUFES during daytime, and performs vertical profiles for the water column description and water sampling, as well as mesozooplankton net casts during night-time; and the marine megafauna observer team ( 3 people) is in charge of cetacean, turtle, large fish and seabird sightings during daytime. The vessel crew comprises 25 to 27 people.

The PELGAS sampling scheme (Figure 1) was designed in 2000, based on fisheries acoustic survey trials conducted in the Bay of Biscay since the mid 1970s, and on findings from the European project CLUSTER (FAIR-CT-96.1799 ended in 1998). It has ever since been completed. Successive improvements and sensor additions are listed in Table 1, summarised in Figure 2, and detailed below.

\section{Acoustic survey}

Acoustic data are collected during daytime ( 06:00 to 22:00 depending on ambient conditions) along systematic line transects perpendicular to the French coast (Figure 1), from Spain in the South to Bretagne in the North, over a total linear distance of approximatively 2000 nautical miles (NM, $1 \mathrm{NM}=1852 \mathrm{~m}$ ). Transects are uniformly spaced every 12 nautical miles $(22 \mathrm{~km})$. The mean size of pelagic fish schools clusters in the Bay of Biscay was estimated at $8 \mathrm{~km}$ (Petitgas, 2003). The inter-transect distance has been chosen to sample the largest number of schools clusters within the given survey time. The nominal vessel speed is 10 knots $\left(1 \mathrm{knot}=1852 \mathrm{~m} \cdot \mathrm{s}^{-1}=1 \mathrm{NM} \cdot \mathrm{s}^{-1}\right)$. This speed has been established as a compromise between maximum travel speed for increased survey coverage and radiated noise. Vessel speed is reduced to an average of 3 knots during fishing operations. The survey design allows for the sampling of Biscay continental shelf ( $23000 \mathrm{NM}^{2}$ ), from $20 \mathrm{~m}$ depth to the shelf break (200 m contour line), with an average 
survey duration of 30 days.

Acoustic data have been continuously recorded through R/V Thalassa II's hull-mounted echosounders during daytime, since the beginning of the time series. Night-time acoustic data have been systematically recorded since 2008, to study the diel cycle of zooplankton and micronekton sound scattering layers (SSLs). In 2000, R/V Thalassa was equipped with three OSSIAN500 vertical echosounders emitting at the nominal frequencies 12, 38 and $200 \mathrm{kHz}$, and one OSSIAN500 49kHz net sounder. OSSIAN echosounders were developed by the French company Micrel in collaboration with Ifremer, specifically for the assessment of pelagic fish biomass and the study fish school features. Furthermore, Thalassa II was equipped with three Simrad EK500 echosounders operated at 12, 38 and $120 \mathrm{kHz}$, providing complementary information on the acoustic scattering properties of acoustically resolvable targets (target strength, TS) (Table 1). In 2004, R/V Thalassa II hull mounted echosounders were replaced by five new generation Simrad EK60 echosounders emitting at $18,38,70,120,200 \mathrm{kHz}$, providing improved quality data (in terms of target strength, target position, and volume backscattering strength measurements; Andersen, 2001). A further innovative equipment, a calibrated multibeam vertical echosounder, the Simrad ME70 (Trenkel et al., 2008), was developed by Simrad in collaboration with Ifremer. Main strength of the ME70 is its ability to overcome sampling bias and limitations identified in both vertical single beam echosounders (range-dependent acoustic beam sampling volume, partial and biased sampling of fish schools; Diner, 2007, 2001), and traditional multibeam sonars (interferences between beams in the water column). It was installed aboard R/V Thalassa II in 2005, and has been routinely used during PELGAS surveys since 2008. The ME70 system is able to provide 3-dimensional (3D) views of the pelagic zone and contained fish schools. Such information is used during PELGAS to better assess the fish school specific composition and density, based on their 3D shape, density and position. This helped to improve the fish target identification strategy (i.e. when to perform identification trawl hauls?), and the allocation of echo recordings to specific fish species during the scrutinising process. In 2005, the EK60 transducers were installed close to each other to allow for best possible beam overlap and improved multifrequency analysis capabilities (Korneliussen et al., 2008). A $333 \mathrm{kHz}$ Simrad EK60 echosounder was added to Thalassa II in 2012. This echosounder is of particular interest to study fluid-like mesozooplankton targets. All EK60 echosounders have a $7^{\circ}$ beam opening, with the exception of the $18 \mathrm{kHz}$ transducer with a $11^{\circ}$ nominal two-ray beam angle. A Simrad EK60 
echosounder operated at $120 \mathrm{kHz}$ was further fitted with a side-looking ellipsoidal transducer (Simrad ES2.5 $\times 10^{\circ}$ ), within one of the vessel moon pools since 2009 . Horizontally orientated echosounders are able to assess the density of fish schools occurring close to the surface, difficult or impossible to assess with traditional vertically oriented echosounders. Generally, the upper $10 \mathrm{~m}$ of the water column (app. 2 times the nearfield zone of the used frequency with the largest nearfield) are excluded from traditional acoustic surveys to mitigate against errors due to the acoustic nearfield, where the acoustic pressure and particle velocity are not in phase. EK60 echosounders have been replaced by Simrad EK80 wide band echosounders during R/V Thalassa II refit in summer 2017. These new echosounders with broadband capabilities should further improve the multifrequency identification of acoustic targets, using a bandwidth of frequencies rather than multiple discrete frequencies (see e.g. Stanton et al., 2010, 2012). All echosounders used during PELGAS were operated at a standardised pulse duration of $1.024 \mathrm{~ms}$ and were calibrated at least once immediately before or after each PELGAS survey, using a standard method (Demer et al., 2015). Transducers emissions times (ping rate) are synchronised through a synchronisation board in order to avoid interferences between echosounders transmitting and receiving in the same band of frequencies. Echosounders have been operated manually prior to 2008, when the Hermes software was introduced. The Hermes software was developed by Ifremer to control the configuration and the ping rate of all echosounders (Trenkel et al., 2009). When located on the continental shelf, the ping rate is automatically adjusted by the Hermes software, as a function of the seabed depth, to avoid false bottom echoes in the water column (Renfree and Demer, 2016). In offshore waters, ping rate is manually adjusted ranging between 0.5 and 2 pings/s to avoid multiple bottom echoes registrations in the 10-150 m layer.

Fish acoustic densities are scrutinised based on spatial and spectral signatures of schools, and associated to trawl catches to derive small pelagic fish biomass estimates, according to the methodology described in Doray et al. (2010), using the dedicated R package EchoR (Doray et al., 2016b).

\section{Fishing}

Acoustic transects are adaptively interrupted to perform identification trawl hauls, to groundtruth acoustic data. Trawls can be seen as alternative biological evidence to acoustic recordings, providing information on the relative species composition of the fish schools, and other biological information such as fish length, 
weight, age, maturity stage, sex, etc. Identification hauls are carried out using the R/V Thalassa II 2 doors, headline: $76 \mathrm{~m}$ foot rope: $70 \mathrm{~m}$ (or $57 \mathrm{~m}$ x $52 \mathrm{~m}$ at depths below $50 \mathrm{~m}$ ) pelagic trawls. Since 2007, a consort survey has been routinely organized together with French pairs trawlers which accompanied R/V Thalassa for approximatively 20 days, to conduct supplementary identification hauls (Massé et al., 2016). Rationale for performing identification haul include: i) observing numerous fish echotraces within 2 to $3 \mathrm{NM}$; ii) noticing changes in the echotrace characteristics; iii) observing an echotrace fished on previous transects, but not on the current transect. Accompanying commercial fishing vessels have been directed by PELGAS scientists toward echotraces to be identified, according to the acoustic registrations recorded by R/V Thalassa II's, and according to the relative fishing efficiency of all vessels involved (pair trawlers are more efficient near the surface and in coastal areas). The participation of commercial fishermen to PELGAS enabled to double the number of identification hauls (from an average of approximately 60 to 120 per survey), hence increasing the precision of the allocation of fish echo recordings to given species. Trawl catches are sorted and analysed after each haul, to characterise the catch specific composition, as well as to obtain length and mean weight distributions, and individual biological parameters for anchovy and sardine (age, length, weight, maturity, etc, see details in Doray et al., 2014). Catches completed by the pair trawlers are sorted by trained scientific observers aboard the fishing vessels. Anchovy and sardine samples are transferred to and analysed aboard R/V Thalassa II. Gelatinous macro-zooplankton in midwater trawl catch are recorded and analysed following a protocol established to obtain information on these components to fulfil MSFD requirements since 2016 (Aubert, 2017).

\section{Hydrobiology}

A hull-mounted Seabird SBE21 thermosalinometer, fitted with temperature, salinity and fluorescence sensors records surface hydrological conditions at a 30 seconds interval during the survey. During daytime, the hydrobiology team operates the CUFES system mounted with a $315 \mu \mathrm{m}$ mesh collector and providing pumped surface (5 m depth) seawater at an average rate of $570 \mathrm{~L} \cdot \mathrm{min}^{-1}$. A CUFES sample is collected every $3 \mathrm{NM}$ ( 18 min) during acoustic sampling. At night, 3 to 4 hydrobiological stations are performed on every other transect, yielding on average a total of 80 stations per survey. The hydrobiology stations are ideally performed on a transect that was surveyed during the previous daytime period, to synoptically capture the 
fish bio-physical environment. This also allows for the adjustment of some of the locations of the stations, according to the hull-mounted thermosalinometer measurements for surface waters, and on the observed egg counts. PELGAS hydrobiological environment sampling scheme is summarized in Figure 1 and 2. Hydrobiological equipment routinely deployed at PELGAS stations include: i) a Conductivity-TemperatureDepth (CTD) probe fitted with auxiliary sensors including a fluorometer, a turbidimeter, an oxygen sensor, a Laser Optical Particle Counter (LOPC, Herman, 2004) and 9 Niskin bottles, ii) 3 WP2 nets (57 cm diameter, $200 \mu \mathrm{m}$ mesh) fitted in a single frame, equipped with a Hydrobios (back-run stop) mechanical flowmeter. CTD vertical profiles are first performed from the sea surface to 5 meter above the seabed, (downcast at approximately $0.8 \mathrm{~m} \cdot \mathrm{s}^{-1}$ ), using a conducting cable that enables the real-time characterization of the water vertical stratification during the downcast. Typically, three sets of three Niskin bottles are fired, based on the real-time observed CTD profile. Bottles are fired when moving up the water column during the upcast to collect water at three defined locations: i) well below the pycnocline, ii) at the deep chlorophyll maximum (DCM, generally near the pycnocline), and iii) at the sea surface. NISKIN bottles content is filtered after deployment, to assess phytoplankton and microzooplankton communities, chlorophyll a (Chl a) biomass, and suspended matter concentration.

From 2003 to 2008, vertical WP2 net tows were exclusively performed in the anchovy core distribution area in the southern Biscay. Since 2009, WP2 sampling has been carried out at all stations to optimise coverage. The WP2 is deployed at $100 \mathrm{~m}$ depth maximum (downcast and upcast $0.5 \mathrm{~m} \cdot \mathrm{s}^{-1}$ ), or at $5 \mathrm{~m}$ above the seabed (if less than $100 \mathrm{~m}$ depth). Further, a "filet Carré" (Bourriau, 1991) fitted with 315 or $500 \mu \mathrm{m}$ mesh nets, and a $315 \mu \mathrm{m}$ mesh-size Multinet (Hydrobios) fitted with 5 nets were also adaptively and opportunistically deployed. The former has mainly been used for sampling fish eggs to derive density gradient columns for egg density measurements (Huret et al., 2016), or grazing experiments as well as for larval sampling. For the latter, the Multinet was towed for stratified sampling and vertical distribution analysis of ichtyoplankton larvae. The first WP2 sample and the CUFES samples were preserved with $4 \%$ buffered formaldehyde (final concentration) and examined under a binocular microscope until 2014. Since 2015, the WP2 and CUFES samples are processed directly aboard, immediately after collection and prior preservation, using the ZooCAM flow imager (Colas et al., this volume). The ZooCAM is an in-flow imaging particle and plankton analyser that has been developed following a collaborative, trans-disciplinary work between teams within 
Ifremer, initiated during PELGAS in 2013. It has so far been utilised to semi-automatically process and count anchovy and sardine eggs in CUFES samples, and to complete the gross taxonomic identification and measurement of mesozooplankton organisms in CUFES and WP2 samples. This hardware development, combined with an ad-hoc image analysis software (Ecotaxa; Picheral et al., 2016), provided an image-based, time-efficient procedure to process ichthyo- and mesozooplankton samples at a lower taxonomic resolution than the very time consuming manual identification. The second WP2 sample is fractionated into 4 size classes $(2000,1000,500$ and $200 \mu \mathrm{m})$ and dry biomass analysis. The third WP2 sample has been destined to other analysis required by ongoing research projects, related to isotopes, genetics or energy density analysis.

\section{Megafauna}

Marine megafauna (marine mammals, marine turtles, large fish, birds), macro-litters and ships are recorded during daytime, along acoustic transects, by two trained observers. Briefly, the data collection protocol follows standard line transect methodology for density estimation with distance sampling methods (Buckland et al., 2015). The precise GPS location of each sighting, distance travelled (vessel speed $>8$ knots) and observation conditions (glare, cloud cover, sea state, etc.) are recorded. Along a given transect, a leg corresponds to a portion of effort prospected in the same conditions. Whenever the conditions change (e.g. a change in ship activity or in sea state), or if the observer is replaced by another observer, a new leg is started. Two observers are operating on either side of the upper bridge (16 meters above sea level) or inside the bridge if outdoor weather conditions are too harsh (14 meters above sea level). The observers are looking for marine megafauna with naked eyes (binoculars were only used for species identification upon detection), within an angle of $90^{\circ}$ from the side to the bow. Identification is carried out to the lowest possible taxonomic level. Pictures are taken to validate species identification for cetaceans, and for seabirds, if in doubt. Every hour, one observer is relieved from duty by the third observer, to prevent observer fatigue. The duration of a single leg is thus at most one hour and observation bouts for any observer are two hours at max, followed by a one hour break. Effort was suspended during trawling operations, but birds following the ship were recorded during trawl hauling in and out. The detailed protocol can be found in Doray et al. (2014),

\section{Ecosystem data management and analysis}


Acoustic and CTD raw data are stored in the French national oceanographic data center SISMER ${ }^{2}$. Preprocessed acoustic and fishing data, as well as PELGAS biomass estimate results are stored in the dedicated relational database EchoBase ${ }^{3}$. Mesozoo- and ichtyo-plankton images are stored online in Ecotaxa (Picheral et al., 2016), a web application dedicated to the visual exploration and the taxonomic annotation of plankton images. Megafauna sighting data are deposited in the OBIS SEAMAP database ${ }^{4}$.

Since 2000, PELGAS data have been mostly analysed ecosystem component per ecosystem component, by respective experts. PELGAS group members however felt in 2013 that new, transdisciplinary, analysis of data across ecosystem components was needed, to do justice to the data series, and further improve the comprehensive understanding of the Biscay pelagic ecosystem functioning. The first challenge faced at the onset of cross ecosystem component analysis was the disparity of sampling scales, that prevented direct data comparison across components (Levin, 1992). This difficulty was mitigated by the development of a simple spatial smoothing procedure in 2008, the block averaging procedure (BAP; Petitgas et al., 2009; Petitgas et al., 2014). This method produces standard raster maps of all parameters collected during PELGAS surveys. BAP is an unsupervised procedure with the ability to spatially interpolate large amounts of ecosystem data, collected according to different sampling schemes, while avoiding edge effects. The application of other, more supervised spatial interpolation techniques, such as geostatistical methods (see review in Chiles and Delfiner, 1999), have been deemed too time consuming, given the large amount of parameters to map every year. Taking advantage of the high spatial resolution of PELGAS discrete (hydrobiological stations) and continuous (acoustic, CUFES, marine megafauna) sampling, a common, reasonably fine $\left(0.25^{\circ} \times 0.25^{\circ}\right)$ common grid could be defined. Hydrobiology being the ecosystem component sampled at the coarsest resolution, the compromise grid mesh was defined so as to ensure that at least one hydrobiological station was comprised in each grid cell. Grid maps proved to be an acceptable and convenient format for sharing ecosystem surveys data at national and international level (see e.g. ICES, 2016).

Multivariate ordination and clustering methods have been applied to a series of grid maps, to identify stable correlation structures between ecosystem parameters describing map cells. Cells with comparable correlation structures across component descriptors displayed coherent spatial patterns, that were used to define sub-

2 http://www.ifremer.fr/sismer/index_EN.htm

3 http://echobase.codelutin.com/v/latest/en/

4 http://seamap.env.duke.edu/dataset/1403 
regions within the Biscay pelagic ecosystem. This map-based approach to analyse the ecosystem complexity allowed to perform direct pairwise comparisons of ecosystem components (Doray et al., this volume-a; Lambert et al., this volume), to describe spatio-temporal dynamics (Doray et al., this volume-b), or to define global pelagic seascapes (Petitgas et al., this volume). Those first attempts to perform cross ecosystem component analysis of PELGAS data confirmed the need for new methodologies to further analyse and describe such complex ecosystem datasets.

The PELGAS model for integrated ecosystem data collection and analysis is summarised in Figure 2.

\section{Advantages and limitations of the PELGAS model}

\section{Collaborative work}

Conducting an integrated ecosystem survey requires collaboration between scientists from various disciplines, to avoid the mere juxtaposition of standard, independent data collection schemes on the same platform, and to ultimately answer a shared scientific question. In the case of PELGAS, scientists from different disciplines first joined forces to better understand anchovy recruitment success, initiating the collaborations needed to conduct the PELGAS integrated ecosystem survey. However, developing effective collaboration within the PELGAS group has not been straightforward. Scientists have a natural tendency to compete with one another for research resources, both during and after the voyage, since the early days of oceanography (Adler, 2014).

Three factors can be put forward which strengthen and furthered the development of collaborative work within the PELGAS group. The first one is the presence of both technicians and researchers in the PELGAS scientific crew. The scientific crew is composed of technicians and engineers specialised in data collection, but also of the researchers, $\mathrm{PhD}$ students and interns who are also in charge of the analysis of the survey data. The annual gathering of researchers from various fields, for relatively long periods of time during PELGAS, certainly helped building bridges between disciplines and laboratories, via informal interactions at sea. Secondly, besides close interactions during the survey, Ifremer and La Rochelle University researchers involved in the analysis of PELGAS data hold joint meetings at least once a year to share methodological advances and results, or plan future surveys and analysis. Thirdly, informal collaborations initiated at sea or 
during PELGAS meetings were further developed within the framework of a national research program (PNEC Gascogne, 2000-2005) and through eight international research projects that included data and concepts derived from the survey (PELASSES, 2000-2002; SIMFAMI, 2001-2005; UNCOVER, 2006-2010; RECLAIM 2006-2010; FACTS, 2010-2012; ATLANTOS, 2015-2019, REPRODUCE, 2010-2012; SEAMAN, 2013-2015). This combination of informal interactions and formal collaborations within research projects, brought the scientists of the PELGAS group to progressively articulate their personal research interests around a broader and scientifically appealing objective: monitoring and understanding the Bay of Biscay pelagic ecosystem. This ambitious objective has emerged and was deemed largely achievable, due to the diversity of PELGAS scientific community. Through this diversity it was possible to regroup the necessary expertise to interpret data collected in separate ecosystem components, as well as concepts and methodologies to collate all the information and derive results at the ecosystem scale. Sharing knowledge on sampling and data analysis methods has been a powerful way to initiate cross ecosystem components studies, either by applying methods used in one component to another (e.g. isotopic methods initially applied to cetaceans and seabirds and thereafter to fish and mesozooplankton, or calorimetry on fish then applied to plankton), or by re-analysing archived data series with a different focus (e.g. analysis of multifrequency fisheries acoustics data to derive new information on meso-zooplankton and micronekton). The emergence of an "ecosystem of scientists", adapted to multidisciplinary collaborative work at sea, and on land, has in this way enabled the development of the ecosystem science produced by the PELGAS project. The PELGAS ecosystem has been further enriched by the participation of commercial fishermen in the survey. Fishermen and scientists have been jointly collecting data needed to assess the Biscay anchovy and sardine biomass since 2007, building a shared diagnostic knowledge base of the state of the stock, as well as mutual trust and good relationships (Massé et al 2016).

\section{Ecosystem sampling}

With the addition of megafauna sightings in 2003 , and the generalisation of mesozooplankton sampling at all stations in 2009, all major Biscay pelagic ecosystem components have been routinely sampled in the same area since 2009. This left no additional shiptime to deploy auxiliary sampling gear. The PELGAS sampling scheme was therefore optimised by adding new sensors to existing gears deployed at fixed stations (addition 
of LOPC, and oxygen, $\mathrm{pH}$, and turbidity sensors to the CTD), and collecting more biological information from trawl sampling (e.g. gelatinous mesozooplankton sampling since 2016, fish stomach contents and fish energy). In order to design meaningful ecosystem level monitoring (sensu Kupschus et al., 2016), new sensors and protocols have been added to the PELGAS survey to bridge knowledge gaps identified in data analysis and/or ecosystem modelling studies. New sampling tools and technologies have been selected to comply with practical constraints (funding, staff requirement, vessel space and time availability, maturity of technology). Vessel availability for testing new protocols also appeared to be a crucial factor for validating enhancements of PELGAS sampling strategy.

In the future, supplementary biological data such as micronekton species composition, isotopes and energy densities of fish and mesozooplankton, as well as stomach contents and contaminants of fish, could be obtained by training the fishing team to collect extra parameters on midwater trawl catches. In the multispecific context of the Bay of Biscay, fish sampling could not be passed completely over to the consort vessels, to free valuable R/V Thalassa II time. This would indeed decrease the precision of biomass indices, as the current trawl sampling rate is just sufficient to ascertain the specific composition of the main fish concentrations. Optical net systems could however be deployed on Thalassa's midwater trawls to assess the species and size composition of fish and micronekton echotraces sampled acoustically within different depth strata (Zwolinski et al., 2014). This would save processing time, that could be re-allocated to other tasks. Due to the lack of shiptime for extra gear deployment, future PELGAS sampling enhancements will also involve the development of en-route, semi-automatic observation systems. Fisheries acoustics have provided en-route, real time, high resolution acoustic views of the small pelagic fish horizontal and vertical distributions, since the beginning of the PELGAS time series. Acoustic sampling revealed pelagic seascapes, that were adaptively sampled with midwater trawls during the survey. Moreover, acoustic multifrequency echograms provide real time information on sound scattering layers produced by large mesozooplankton and micronekton (Lavery et al., 2007), that might be further explored to characterise these communities. Acoustically-guided, adaptive sampling could hence complement the traditional discrete sampling at fixed "observing stations" (Adler, 2014), carried out at night during PELGAS. Using ship or sonde-based broadband echosounders (Stanton et al., 2010, 2012) should moreover allow for a more precise acoustic characterisation of echotraces, and provide further insights into the taxonomic stratification of acoustic 
seascapes. Hull-mounted thermosalinometer and the CUFES/ZooCam combination provide en-route, high resolution data on the hydrology, Chl-a, and the abundance of mesozoo- and ichtyo-plankton in the acoustic blind zone (0-10 m depth). Pelagic seascapes near the sea surface could be defined by applying an approach described by Petitgas et al. (this volume). This includes the development of standard raster maps of significant descriptors collected by the CUFES and the thermosalinometer. Those hydrobiological pelagic seascapes could also be compared to SSLs and fish concentrations detected by vertical echosounders in the 10-30 m layer, or by the lateral echosounder in the 0-10 m depth layer, to further characterise the small pelagic fish habitats near the sea surface (see e.g. Doray et al., this volume-a). The installation of a FerryBox (Petersen, 2014) on R/V Thalassa II in summer 2017 will allow the collection en-route of additional data on oxygen, $\mathrm{pH}$, coloured dissolved organic matter concentration (CDOM), and algae groups by fluorescence spectroscopy. In depth sampling of Biscay hydrology and plankton en route could eventually be conducted by deploying an undulating towed body (Bruce and Aiken, 1975) equipped with CTDs and optical or imaging particle and plankton counters (Herman, 2004). The rapid increase of satellite-based bandwidth could eventually allow to remotely control some sampling or data processing operations aboard research vessels or other platforms. This could free valuable vessel space for scientists conducting new sampling (Zwolinski et al., 2014). Real time remote controlled data flux management of several sampling platforms could also allow to adaptively combine vessel-borne sampling with observations realised on other platforms (e.g. autonomous moving subsea platforms, drones, fixed platforms, buoys etc. cf. Godo et al., 2014) to improve sampling coverage and/or resolution.

Development of en-route and/or semi-automatic systems enabling the extension of PELGAS sampling coverage has generated new, voluminous, data fluxes that need to be securely archived and processed within a reasonable delay. New hardware and software have been developed to accommodate these new large ecosystem data fluxes, with the common objective of processing onboard as much data as possible, to take advantage of the availability and expertise of the scientific team during the survey (e.g. ZooCAM).

\section{Ecosystem data analysis}

Biomass and abundance indices of chub mackerel (Scomber colias), Atlantic mackerel (Scomber scombrus), horse mackerel (Trachurus trachurus), blue whiting (Micromesistius poutassou), European anchovy 
(Engraulis encrasicolus), European sardine (Sardina pilchardus) and sprat (Sprattus sprattus) have been derived every year from PELGAS data since 2000 (Figure 3). Anchovy and sardine biomass and abundance at age have also been routinely computed. PELGAS has provided the ICES WGHANSA stock assessment working group with a relative estimate of the springtime Biscay anchovy adult biomass since 2000. The stock biomass has dropped in 2002, leading to the fishery closure from 2005 to 2010 (Figure 3). Anchovy biomass remained low due to recruitment failure until 2010. The fishery was re-opened in 2010, based on the relatively high survey biomass indices. Bay of Biscay anchovy stock biomass has remained high since 2010, following the implementation of more conservative Harvest Control Rules in 2009 (COM, 2009). The PELGAS biomass index has been combined in an analytical stock assessment model with the other survey indices and commercial fishery landings, to assess the state of Biscay anchovy stock, and provide the European Commission with an advice on Total Allowable Catch (ICES, 2015). A biomass estimate of the sardine stock component present in Biscay in springtime has also been derived from PELGAS survey data since 2000 (Figure 3), and communicated to ICES WGHANSA. This index has been used to assess the state of the data limited sardine stock in the Bay of Biscay and the English Channel (ICES, 2015). PELGAS biomass estimates and size structures of Atlantic mackerel, horse mackerel, blue whiting and boarfish have been provided to the ad-hoc ICES WGWIDE stock assessment working group since 2016. The precision and robustness of small pelagic fish biomass indices derived from acoustic-trawl PELGAS data have been investigated by: i) assessing underlying parameters (e.g. fish Target Strength; Doray et al., 2016a), and methods, (Petitgas et al., 2003) used in the acoustic biomass estimation procedure, and ii) jointly analysing egg-based and acoustic-based fish biomass estimates, to identify potential annual sampling bias in both methods (Petitgas et al., 2009).

The PELGAS survey model allowed for the collection of long-term time series of spatially-explicit data in the main Bay of Biscay pelagic ecosystem components (hydrology, phytoplankton, mesozooplankton, fish and megafauna). The BAP mapping procedures defined by the PELGAS consortium allowed to routinely produce maps of parameters collected in the ecosystem main components, in addition to biomass indices for fish stock assessments (Figure 2).

Numerical ecologists and fisheries oceanographers have collaborated since the onset of the PELGAS survey to apply and further adopt statistical and mechanistic models to ecosystem data collected during the survey. 
PELGAS data has hence contributed to the publication of over 70 peer-reviewed articles and $9 \mathrm{PhD}$ theses since the year 2000 up until 2017.

Statistical models have been applied to study the interannual variability of spatial distributions and in particular to define and characterise marine habitats, i.e. the environmental conditions that are favourable for the presence of prevalence of an organism (Petitgas et al., 2014). Hence the PELGAS georeferenced ecosystem data have been used to study statistical relationships between ecosystem components, in a spatial context. The interannual variability of the spatial distributions of various ecosystem variables have been modelled. These include hydrological parameters, to define typical "hydrological landscapes" (Planque et al., 2006); plankton and fish spatial abundance, to explore relations between the trophic state of the system, planktonic community structure, and fish distributions (Petitgas et al., 2006; Vandromme et al., 2014); small pelagic fish egg densities, to assess temporal changes in spawning (Bellier et al., 2007); adult pelagic fish densities, to characterise nested aggregative structures (Petitgas 2003), "acoustic populations" (Petitgas et al., 2003), spatial segregation in size and species (Petitgas et al., 2011; Certain et al., 2011), and relationships between recruitment and adult spatial patterns (Petitgas et al., 2014); cetacean and seabirds abundance, to define habitats (Certain et al., 2008), and to investigate predator-prey interactions (Certain et al., 2011) and vulnerability to pressure (Certain et al., 2015).

Data and concepts derived from PELGAS surveys have been incorporated/tested in mechanistic models of the Bay of Biscay pelagic ecosystem processes since the onset of the time series. In addition to contributions to the study of surface circulation (Charria et al., 2013; Reverdin et al., 2013) and toxic algae blooms (Batifoulier et al., 2013) in the Bay of Biscay, PELGAS hydrological data have contributed in groundtruthing the MARS3D hydrodynamic model (Lazure et al., 2009) of the Bay of Biscay, and its biogeochemical extension, ECOMARS (Huret et al., 2013). A biophysical Individual Based Model of the growth and survival of anchovy early life stages was developed based on PELGAS data and the MARS hydrodynamic model (Allain et al., 2007b; Huret et al., 2010) to investigate larval dispersal and survival, predict anchovy recruitment (Allain et al., 2007a; Huret et al., 2010), and test the effect of climate scenarii on anchovy larval dispersal (Lett et al., 2010). Furthermore, PELGAS data (Dubreuil and Petitgas, 2009; Gatti et al., this volume) were used to calibrate a bioenergetic model of Biscay anchovy (Pecquerie et al., 2009; Gatti et al., 2017) and sardine (Gatti et al., 2017). This model was implemented to complement earlier 
studies (Bellier et al., 2007) aiming at predicting anchovy spawning potential habitats (Pecquerie et al., 2009), and to explore spawning migrations, based on ECOMARS model outputs (Politikos et al., 2015). Knowledge and data on the Bay of Biscay small pelagic fish life cycles from PELGAS surveys has been compiled in a review of the North-East Atlantic small pelagic fish life cycles (ICES, 2010) and used to investigate the recent expansion of anchovy populations in the North Sea (Petitgas et al., 2012). The PELGAS survey has shed light on the Bay of Biscay pelagic ecosystem global functioning. This has been generally achieved through the analysis of trophic interactions between components. Modelling studies using PELGAS data have investigated the carbon transfer from low to high trophic levels in the Bay of Biscay (Lassalle et al., 2011; Marquis et al., 2011, 2007). Effects of mesozooplankton productivity on anchovy population have been studied using biochemicals markers from PELGAS samples (Bergeron and Massé, 2011; Bergeron et al., 2013). PELGAS has provided biological samples to assess the energy content of cetacean preys species (Spitz et al., 2010; Spitz and Jouma'a, 2013) and the isotopic signature of consumers in spring in the Bay of Biscay (Chouvelon et al., 2012;.Chouvelon et al., 2014; Chouvelon et al., 2015). PELGAS data have been used to calibrate the ISIS-FISH fishery simulation model (Lehuta et al., 2013) to assess the efficiency of Biscay anchovy fisheries management scenarii (Lehuta et al., 2010). Potential impacts of fisheries on cetacean populations in the Bay of Biscay have been assessed using trophic network models including PELGAS data (Lassalle et al., 2012). Hydrodynamic and later complex ecosystem models allowed to extrapolate the time restricted observations realised during the survey into a larger, seasonal or inter-annual context, and to test hypothesis on ecological processes and global change effects on the ecosystem.

Further papers presented in this volume provide new insights into ecological processes taking place in single components of the Bay of Biscay pelagic ecosystem. Perrot et al. (this volume) for example showed how water samples collected during the PELGAS 2012 to 2015 surveys can be used to groundtruth the results of an ocean color algorithm aiming at detecting phytoplanktonic coccolithophores. Dessier et al. (this volume) provided new insights on mesozooplankton spatio-temporal distribution and energy content in southern Bay of Biscay. Gatti et al. (this volume) presented new results on adult anchovy and sardine energy content along a latitudinal gradient, and across different age stages. Authier et al. (this volume) documented changing patterns in the relative abundance of marine megafauna at a community level, based on a decade worth of 
PELGAS data (2004-2016). Huret et al. (this volume) proposed to correct the actual dates of the annual survey with respect to a climatology of the seasonal evolution of surface temperature, allowing for an improved interpretation of the observed interannual anchovy and sardine spawning variations. Crossecosystem component studies resulting from new collaborative work were also presented. Most are based on the standard raster maps of ecosystem parameters collected during PELGAS (Figure 2). Doray et al. (this volume-a) have defined spring habitats of small pelagic fish communities in the Bay of Biscay, and assessed their variability based on information collected over an entire decade. Lambert et al. (this volume) have explored the fluctuations in habitat preferences exhibited by five mobile top predators species within the Bay of Biscay. Spitz et al. (this volume) have studied the predation of cetaceans on small pelagic fish based on stomach content analysis. Petitgas et al. (this volume) have combined the standard maps of parameters collected in the main components of the Biscay pelagic ecosystem over the 2009-2014 period, to define a map of ecosystem seascapes that are consistent over the years, paired with a map of inter-annual variability. Doray et al. (this volume-b) have selected series of potential pelagic ecosystem indicators derived from the PELGAS survey, to identify the main ecological processes that have been dominant in the Bay of Biscay since the year 2000, and to test the effects of external forcing on the ecosystem dynamics.

\section{Limitations and challenges}

PELGAS has been evaluated against the "ideal" integrated survey for ecosystem approach defined by ICES (ICES, 2012). According to this evaluation, the main step that would be required for the PELGAS survey to move from its current state to the ideal ecosystem survey would be to extend its coverage to the demersal ecosystem (ICES, 2012). The main limitation of PELGAS being dedicated R/V Thalassa II vessel time, at this point it would not be possible to simultaneously monitor both pelagic and demersal ecosystems in Biscay in spring, without chartering another vessel, or doubling the survey duration. As the Bay of Biscay demersal resources are assessed in autumn, during the EU DCF funded EVHOE bottom trawl survey (Mahé, 1987), duplicating this coverage in spring during PELGAS is not considered a key priority.

Even if process studies have been opportunistically carried out during PELGAS to bridge knowledge gaps on for example phytoplankton production, zooplankton grazing, vertical distribution of eggs and larvae, fish Target Strength variation with depth, identification of sound scattering layers or remotely sensed blooms etc. 
(cf. Table 1), one of the major limitation of the PELGAS survey is the absence of long-term sampling effort dedicated to process studies. In spite of the fact the survey has been designed by researchers and has always been integrated into national ecology programs, the standard data collection over the survey grid has been disconnected from process understanding. Conducting process studies alongside standard data collection during a survey is however a daunting task, as sharing vessel space and time, as well as harmonising sampling coverage over all ecosystem components for maintaining standard data collection remains one of the major challenges faced during PELGAS. Recent outbreaks of mesozooplankton or micronekton distributions and abundances have been qualitatively observed during PELGAS (salps in 2014, 2015, pteropods and to a lesser extent euphausiids in 2016, unpublished data). These observations suggest that extending the PELGAS sampling to more extensivley cover those data poor, but potentially ecologically and biogeochemically important (Banse, 1995; Lehodey et al., 2015) intermediate trophic levels could be crucial step towards a better understanding of the dynamics and functioning of the pelagic ecosystem, especially in the context of climate change (Richardson, 2008). En-route multifrequency acoustic data routinely collected during PELGAS bears the potential to produce improved information on intermediate trophic levels spatial distribution, providing that ground-truth data are available (Mair et al., 2005). Collecting ground-truth data on intermediate trophic levels would however require supplementary gear deployments, that are not fully compatible with the survey schedule at this stage. More detailed information on phytoplankton diversity should also be collected. Further information on organisms that are known to play major roles in marine ecosystem such as bacteria, viruses and parasites (e.g. of fishes) remain sparse.

However, extending sampling activities cannot be carried out endlessly without compromising data quality (Shephard et al., 2015). Choosing between maintaining standard data series for fulfilling new MSFD and DCF requirements, or conducting process-based studies might become in a near future a dilemma faced by integrated ecosystem surveys. This is why a regular survey protocol evaluation and adaptation (cf. Kupschus et al., 2016) during WGACEGG and PELGAS annual meetings, as well as sampling automation, are crucial to keep improving integrated ecosystem survey coverage, without compromising the quality of existing longterm data series.

\section{Perspectives for ship-based ecosystem monitoring}


The PELGAS survey has demonstrated since the year 2000 that the collection of integrated data on diverse ecosystem components during a single-species fish biomass assessment survey is possible and useful in the context of an EAF. The PELGAS ecosystem approach has inspired some European scientists in promoting other surveys, contributing to a general move from single-species fish biomass assessment to a wider ecosystem approach. Following PELGAS example, hydrobiological sampling and cetacean and seabird sightings have now been added to the bottom trawl surveys conducted by Ifremer on R/V Thalassa II covering the Bay of Biscay and the Celtic Sea (EVHOE; Mahé, 1987), the English Channel and the North Sea (French contribution to IBTS; Vérin, 1992). PELACUS (Bode et al., this volume), PELGAS' Spanish counterpart survey aiming at assessing small pelagic fish biomass in Cantabrian and Galician waters through AT surveys, has been conducted on R/V Thalassa II from 1997 to 2012. Conducting coordinated surveys on the same platform permitted to strengthen the exchanges and collaborations between French and Spanish scientists initiated during the PELASSES project. A major strength is that both parties benefited from the same equipments, and were able to commonly develop ecosystem sampling strategies during both PELACUS and PELGAS. Other fisheries acoustic surveys coordinated since 2002 within the ICES ACEGG working group have also been inspired by the PELGAS' ecosystem approach, namely PELAGO (Portugal), JUVENA (Spain; Boyra et al., 2013), and PELTIC (United Kingdom; ICES, 2016, p. 331).

The adoption of MSFD in 2008 has renewed the interest in ecosystem surveys in Europe, as they could become the backbone of ecosystem data collection in the offshore areas covered within the directive. MSFD aims to achieve Good Environmental Status (GES) in European Union waters by 2020 (MSFD, 2008/56/EC), through improved management, based on supporting state indicators. PELGAS has in a way anticipated MSFD requirements by collecting observations and deriving potential indicators of the state of the Bay of Biscay pelagic ecosystem in spring since 2000. Table 2 presents a list of potential ecosystem indicators that have been derived from PELGAS data, including spatial indices proposed by Woillez et al. (2007). An example of the combination and synthesis of PELGAS indicators series to study the Biscay pelagic ecosystem dynamics over time is presented in Doray et al. (this volume-b). The PELGAS group intends to continue the development of new potential indicators of the pelagic ecosystem state, and indicators combination methods, to contribute to the operationalisation of ecosystem management. While ambitious marine ecosystem management objectives have been adopted in Europe within the MSFD framework, the 
tension between the economic cost of MSFD Monitoring Programs and the need to produce data to derive supporting state indicators has been outlined (Shephard et al., 2015; Borja and Elliott, 2013). Ecosystem surveys being logistically complex and expensive to run, the EU DCF funding of PELGAS has been essential for the continuous development and maintenance of this long term ecosystem survey. The future of PELGAS and other ecosystem surveys in Europe will likely depends on the member states willingness and ability to provide sufficient funds for further developing and maintaining Monitoring Programs up to the challenge of MSFD objectives.

\section{Conclusions}

PELGAS has been developed as an integrated ecosystem survey, aiming at assessing adult anchovy biomass and predicting recruitment success in the Bay of Biscay in spring, in the context of an EAF. Sampling has been progressively extended to other ecosystem components, and the PELGAS survey focus has shifted to become an ever more efficient and holistic monitoring program of the Bay of Biscay pelagic ecosystem, while conserving its initial objective of estimating the target species biomass for assessment purposes. The PELGAS survey has hence confirmed that acoustic-trawl survey could be the backbone for development of a pelagic ecosystem survey (Zwolinski et al., 2014).

PELGAS data have been analysed using statistical models to improve knowledge on single ecosystem components and to compare data from different components or sampling tools. This cross component and data source approach was used to control for sampling bias, as well as to track changes in the ecosystem, and further investigate their causes. Deterministic modelling has been used to integrate ecosystem knowledge, and hypothesis testing on ecological processes. Each new PELGAS survey is however the definitive crashtest for ecological hypotheses, as the diverse and dynamic Bay of Biscay spring pelagic ecosystem is often full of surprises. Despite the new knowledge on Bay of Biscay anchovy population dynamics derived from the PELGAS survey, the recruitment success of this species remains relatively unpredictable. Anchovy recruitment variability was found to be correlated with several environmental parameters, but these correlations have thereafter failed their predictive power (ICES, 2010). An end-to-end model of Bay of Biscay anchovy life cycle, integrating PELGAS data, is currently under development, to further investigate 
the ecological processes driving the anchovy population dynamics and recruitment success.

In the MSFD context, the PELGAS time series of potential indices on the Biscay pelagic ecosystem state could contribute to inform forthcoming ecosystem based management plans of European waters. However, all data that would be needed to integrate all ecosystem components will probably never be collected during a single PELGAS survey. The integration of PELGAS products within larger scale ecosystem programs should therefore be pursued. PELGAS can e.g. serve as a data collection platform for providing near real time groundtruthing data for satellite imaging products. International survey coordination within the ICES ACEGG group now allows for the monitoring of small pelagic fish resources and of some key features of their environment from Gibraltar to Ireland (Massé et al., In press). The PELGAS survey should however be included in a larger ecosystem monitoring program, integrating operational oceanography products, and data fluxes from seabed observatories, buoys, drifters and ships of opportunity (e.g. Dexter and Summerhayes, 2010; Godo et al., 2014), to build efficient MSFD-targeted Joint Monitoring Programs. Such joint monitoring programs could resolve multiscale ecosystem dynamics, through for example combining mesoscale snapshots provided by vessel-based surveys, with continuously collected variations at restricted locations by moored observation platforms. In any case, the recent trend towards operationalisation of marine ecosystem management in a changing world reinforces the need for PELGAS-like ecosystem surveys, to serve as efficient data and concept providers for ecosystem management and research.

\section{Acknowledgements}

This study was supported by Ifremer. PELGAS surveys have been funded by the European Common Fishery Policy Data Collection Framework, the Marine Strategy Framework Directive, and Ifremer. We want to acknowledge the joint efforts of R/V Thalassa crews and PELGAS scientists that made the survey possible. The authors particularly thank Pierre Beillois, Ludovic Bouché, Jean-Hervé Bourdeix, Patrick Grellier, Sophie Le Mestre, Patrick Lespagnol, Françoise Mornet, Laurence Pennors, Philippe Pineau, to the numerous PhD and master students, and to the Marine Mammal \& Seabird Observers. We are indebted to Dr. Sven Gastauer for editing the English text.

\section{References}


Adler, A., 2014. The Ship as Laboratory: Making Space for Field Science at Sea. J. Hist. Biol. 47, 333-362. doi:10.1007/s10739-013-9367-7

Agnew, D.J., 1997. The CCAMLR Ecosystem Monitoring Programme. Antarct. Sci. 9. doi:10.1017/S095410209700031X

Allain, G., Petitgas, P., Lazure, P., 2007a. The influence of environment and spawning distribution on the survival of anchovy (Engraulis encrasicolus) larvae in the Bay of Biscay (NE Atlantic) investigated by biophysical simulations. Fish Ocean. 16, 506-514.

Allain, G., Petitgas, P., Lazure, P., Grellier, P., 2007b. Biophysical modelling of larval drift, growth and survival for the prediction of anchovy (Engraulis encrasicolus) recruitment in the Bay of Biscay (NE Atlantic). Fish Ocean. 16, 489-505.

Andersen, L.N., 2001. The new Simrad EK60 scientific echosounder system. J Acoust Soc Am 109, 2336.

Aubert, A., 2017. Protocole DCSMM d'échantillonnage macro- et méga- zooplancton gélatineux pour campagnes halieutiques IFREMER. Programme de Surveillance DCSMM. http://doi.org/10.13155/50398

Authier, M., Ghislain, D., Canneyt Olivier, V., Jean-Jacques, B., Gérard, G., Mathieu, D., Erwan, D., Jacques, M., Pierre, P., Vincent, R., Jérôme, S., this volume. Exploring Change in the Relative Abundance of Marine Megafauna in the Bay of Biscay, 2004-2016. Prog. Oceanogr. doi:10.1016/j.pocean.2017.09.014

Banse, K., 1995. Zooplankton: Pivotal role in the control of ocean production. ICES J. Mar. Sci. 52, 265-277. doi:10.1016/1054-3139(95)80043-3

Batifoulier, F., Lazure, P., Velo-Suarez, L., Maurer, D., Bonneton, P., Charria, G., Dupuy, C., Gentien, P., 2013. Distribution of Dinophysis species in the Bay of Biscay and possible transport pathways to Arcachon Bay. J. Mar. Syst. 109-110, S273-S283. doi:10.1016/j.jmarsys.2011.12.007

Bellier, E., Planque, B., Petitgas, P., 2007. Historical fluctuations in spawning location of anchovy (Engraulis encrasicolus) and sardine (Sardina pilchardus) in the Bay of Biscay during 1967-73 and 2000-2004. Fish Ocean. 16, 1-15.

Bergeron, J.-P., Koueta, N., Massé, J., 2013. Interannual fluctuations in spring pelagic ecosystem productivity in the Bay of Biscay (northeast Atlantic) measured by mesozooplankton aspartate transcarbamylase activity and relationships with anchovy population dynamics. Fish. Res. 143, 184-190. doi:10.1016/j.fishres.2013.02.006

Bergeron, J.-P., Massé, J., 2011. Change in the shoaling behaviour and nutritional condition of anchovies (Engraulis encrasicolus L.) during a wind-induced water column disturbance: a natural event test of a general hypothesis. Mar. Freshw. Behav. Physiol. 44, 93-107. doi:10.1080/10236244.2011.568600

Blaxter, J.H.S., Hunter, J.R., 1982. The Biology of the Clupeoid Fishes, in: Advances in Marine Biology. Elsevier, pp. 1-223. doi:10.1016/S0065-2881(08)60140-6

Bode, A., Carrera, P., González-Nuevo, G., Nogueira, E., Riveiro, I., Santos, M.B., this volume. A trophic index for sardine (Sardina pilchardus) and its relationship to population abundance in the southern Bay of Biscay and adjacent waters of the NE Atlantic. Prog. Oceanogr. doi:10.1016/j.pocean.2017.08.005

Borja, Á., Elliott, M., 2013. Marine monitoring during an economic crisis: The cure is worse than the disease. Mar. Pollut. Bull. 68, 1-3. doi:10.1016/j.marpolbul.2013.01.041

Bourriau, P., 1991. The "Carré Net." ICES CM 1991/L:53.

Boyra, G., Martinez, U., Cotano, U., Santos, M., Irigoien, X., Uriarte, A., 2013. Acoustic surveys for juvenile anchovy in the Bay of Biscay: abundance estimate as an indicator of the next year's recruitment and spatial distribution patterns. ICES J. Mar. Sci. 70, 1354-1368. doi:10.1093/icesjms/fst096

Bruce, R.H., Aiken, J., 1975. The undulating oceanographic recorder? A new instrument system for 
sampling plankton and recording physical variables in the euphotic zone from a ship underway. Mar. Biol. 32, 85-97. doi:10.1007/BF00395162

Buckland, S.T., Rexstad, E.A., Marques, T.A., Oedekoven, C.S., 2015. Distance Sampling: Methods and Applications, Methods in Statistical Ecology. Springer International Publishing, Cham. doi:10.1007/978-3-319-19219-2

CalCOFI, 2011. State of the California Current 2010-2011: Regional Variable Responses to a Strong (But Fleeting?) La Niña. CalCOFI Report No. 52.

Certain, G., Jorgensen, L.L., Christel, I., Planque, B., Bretagnolle, V., 2015. Mapping the vulnerability of animal community to pressure in marine systems: disentangling pressure types and integrating their impact from the individual to the community level. ICES J. Mar. Sci. 72, 1470-1482. doi:10.1093/icesjms/fsv003

Certain, G., Massé, J., Van Canneyt, O., Petitgas, P., Doremus, G., Santos, M.B., Ridoux, V., 2011. Investigating the coupling between small pelagic fish and marine top predators using data collected from ecosystem-based surveys. Mar. Ecol. Prog. Ser. 422, 23-39.

Certain, G., Ridoux, V., van Canneyt, O., Bretagnolle, V., 2008. Delphinid spatial distribution and abundance estimates over the shelf of the Bay of Biscay. ICES J Mar Sci 65, 656-666.

Charria, G., Lazure, P., Le Cann, B., Serpette, A., Reverdin, G., Louazel, S., Batifoulier, F., Dumas, F., Pichon, A., Morel, Y., 2013. Surface layer circulation derived from Lagrangian drifters in the Bay of Biscay. J. Mar. Syst. 109-110, S60-S76. doi:10.1016/j.jmarsys.2011.09.015

Checkley Jr, D.M., Ortner, P.B., Settle, L.R., Cummings, S.R., 1997. A continuous, underway fish egg sampler. Fish. Oceanogr. 6, 58-73. doi:10.1046/j.1365-2419.1997.00030.x

Chiles, J., Delfiner, P., 1999. Geostatistics: Modeling Spatial Uncertainty. Wiley, New York (USA).

Chouvelon, T., Chappuis, A., Bustamante, P., Lefebvre, S., Mornet, F., Guillou, G., Violamer, L., Dupuy, C., 2014. Trophic ecology of European sardine Sardina pilchardus and European anchovy Engraulis encrasicolus in the Bay of Biscay (north-east Atlantic) inferred from $\delta 13 \mathrm{C}$ and $\delta 15 \mathrm{~N}$ values of fish and identified mesozooplanktonic organisms. J. Sea Res. 85, 277-291.

Chouvelon, T., Spitz, J., Caurant, F., Mèndez-Fernandez, P., Chappuis, A., Laugier, F., Le Goff, E., Bustamante, P., 2012. Revisiting the use of $\delta 15 \mathrm{~N}$ in meso-scale studies of marine food webs by considering spatio-temporal variations in stable isotopic signatures - The case of an open ecosystem: The Bay of Biscay (North-East Atlantic). Prog. Oceanogr. 101, 92-105. doi:10.1016/j.pocean.2012.01.004

Chouvelon, T., Violamer, L., Dessier, A., Bustamante, P., Mornet, F., Pignon-Mussaud, C., Dupuy, C., 2015. Small pelagic fish feeding patterns in relation to food resource variability: an isotopic investigation for Sardina pilchardus and Engraulis encrasicolus from the Bay of Biscay (north-east Atlantic). Mar. Biol. 162, 15-37. doi:10.1007/s00227-014-2577-5

Colas, F., Tardivel, M., Forest, B., Perchoc, J., Lunven, M., Guyader, G., Danielou, M.-M., Le Mestre, S., Bourriau, P., Antajan, E., Sourisseau, M., Huret, M., Petitgas, P., Romagnan, J.B., this volume. The ZooCAM, a new in-flow imaging system for fast onboard counting, sizing and classification of fish eggs and metazooplankton. Prog. Oceanogr.

COM, 399 final, 2009. Proposal for a COUNCIL REGULATION establishing a long term plan for the anchovy stock in the Bay of Biscay and the fisheries exploiting that stock. SEC(2009) No. 1076 final.

Demer, D.A., Berger, L., Bernasconi, L., Bethke, E., Boswell, K.M., Chu, D., Domokos, R., Dunford, A.J., Faessler, S.M.M., Gauthier, S., Hufnagle Jr, L.C., Jech, J.M., Le Bouffant, N., Lebourges-Dhaussy, A., Lurton, X., Macaulay, G.J., Perrot, Y., Ryan, T.E., ParkerStetter, S., Stienessen, S., Weber, T., Williamson, N., 2015. Calibration of acoustic instruments. ICES Coop. Res. Rep. 133.

Dessier, A., Bustamante, P., Chouvelon, T., Huret, M., Pagano, M., Marquis, E., Rousseaux, F., 
Pignon-Mussaud, C., Mornet, F., Bréret, M., Dupuy, C., this volume. The spring mesozooplankton variability and its relationship with hydrobiological structure over year-toyear changes (2003-2013) in the southern Bay of Biscay (North-East Atlantic). Prog. Oceanogr.

Dexter, P., Summerhayes, C.P., 2010. Ocean Observations - the Global Ocean Observing System (GOOS), in: Pugh, D., Holland, G. (Eds.), Troubled Waters: Ocean Science and Governance. CUP, Cambridge, pp. 161-178.

Diner, N., 2007. Evaluating uncertainty in measurements of fish shoal aggregate backscattering cross-section caused by small shoal size relative to beam width. Aquat Living Resour 20, $117-121$.

Diner, N., 2001. Correction on school geometry and density: approach based on acoustic image simulation. Aquat Living Resour 14, 211-222.

Doray, M., Badts, V., Massé, J., Duhamel, E., Huret, M., Doremus, G., Petitgas, P., 2014. Manual of fisheries survey protocols. PELGAS surveys (PELagiques GAScogne). Manuel des protocoles de campagne halieutique Ifremer No. 30259.

Doray, M., Berger, L., Le Bouffant, N., Coail, J.Y., Vacherot, J.P., de La Bernardie, X., Morinière, P., Lys, E., Schwab, R., Petitgas, P., 2016a. A method for controlled target strength measurements of pelagic fish, with application to European anchovy (Engraulis encrasicolus). ICES J. Mar. Sci. 73, 1987-1997. doi:10.1093/icesjms/fsw084

Doray, M., Duhamel, E., Huret, M., Petitgas, P., Massé, J., 2000. PELGAS. http://dx.doi.org/10.18142/18

Doray, M., Massé, J., Petitgas, P., 2010. Pelagic fish stock assessment by acoustic methods at Ifremer. Rapp Int Ifremer DOP/DCN/EMH 10-02, 1-17.

Doray, M., Petitgas, P., Huret, M., this volume-a. Spring habitats of small pelagic fish communities in the Bay of Biscay. Prog. Oceanogr.

Doray, M., Petitgas, P., Huret, M., Duhamel, E., Romagnan, J.B., Authier, M., Dupuy, C., Spitz, J., this volume-b. Monitoring small pelagic fish in the Bay of Biscay ecosystem, using indicators from integrated survey. Prog. Oceanogr.

Doray, M., Petitgas, P., Saraux, C., Cornou, A.S., 2016b. EchoR: R package for computing indices of the state of fish population and communities, based on fisheries acoustic data, $\mathrm{R}$ package. https://forge.ifremer.fr/plugins/mediawiki/wiki/echor/index.php/Accueil

Dubreuil, J., Petitgas, P., 2009. Energy density of anchovy Engraulis encrasicolus in the Bay of Biscay. J Fish Biol 74, 521-534.

Eriksen (Ed.), 2014. Survey report from the joint Norwegian/Russian ecosystem survey in the Barents Sea and adjacent waters, August-October 2014, IMR/PINRO Joint Report Series.

Eriksen, E., Gjøsæter, H., Prozorkevich, D., Shamray, E., Dolgov, A., Skern-Mauritzen, M., Stiansen, J.E., Kovalev, Y., Sunnanå, K., this volume. From single species surveys towards monitoring of the Barents Sea ecosystem. Prog. Oceanogr. doi:10.1016/j.pocean.2017.09.007

Fréon, P., Misund, O., 1999. Dynamics of Pelagic Fish Distribution and Behaviour: Effects on Fisheries and Stock Assessment. Blackwell Science, London.

Garcia, S.M., Zerbi, A., Aliaume, C., Do Chi, T., Lasserre, G., 2003. The ecosystem approach to fisheries. FAO Fisheries Technical Paper No. 443. FAO, Rome.

Gatti, P., Cominassi, L., Duhamel, E., Grellier, P., Le Delliou, H., Le Mestre, S., Petitgas, P., Rabiller, M., Spitz, J., Huret, M., this volume. Bioenergetics condition of anchovy and sardine in the Bay of Biscay and English Channel in 2014. Prog. Oceanogr.

Gatti, P., Petitgas, P., Huret, M., 2017. Comparing biological traits of anchovy and sardine in the Bay of Biscay: A modelling approach with the Dynamic Energy Budget. Ecol. Model. 348, 93-109. doi:10.1016/j.ecolmodel.2016.12.018

Godo, O.R., Handegard, N.O., Browman, H.I., Macaulay, G.J., Kaartvedt, S., Giske, J., Ona, E., 
Huse, G., Johnsen, E., 2014. Marine ecosystem acoustics (MEA): quantifying processes in the sea at the spatio-temporal scales on which they occur. ICES J. Mar. Sci. 71, 2357-2369. doi:10.1093/icesjms/fsu116

Herman, A.W., 2004. The next generation of Optical Plankton Counter: the Laser-OPC. J. Plankton Res. 26, 1135-1145. doi:10.1093/plankt/fbh095

Hjort, J., 1914. Fluctuations in the great fisheries of Northern Europe viewed in the light of biological research. Rapp. Procès Verbaux CIEM 20, 227.

Huret, M., Bourriau, P., Doray, M., Gohin, F., Petitgas, P., this volume. Survey timing vs. ecosystem scheduling: degree-days to underpin observed variability with application to anchovy and sardine spawning in the Bay of Biscay. Prog. Oceanogr.

Huret, M., Bourriau, P., Gatti, P., Dumas, F., Petitgas, P., 2016. Size, permeability and buoyancy of anchovy (Engraulis Encrasicolus) and sardine (Sardina Pilchardus) eggs in relation to their physical environment in the Bay of Biscay. Fish. Oceanogr. 25, 582-597. doi:10.1111/fog. 12174

Huret, M., Petitgas, P., Woillez, M., 2010. Dispersal kernels and their drivers captured with a hydrodynamic model and spatial indices: A case study on anchovy (Engraulis encrasicolus) early life stages in the Bay of Biscay. Prog. Oceanogr. 87, 6-17. doi:10.1016/j.pocean.2010.09.023

Huret, M., Sourisseau, M., Petitgas, P., Struski, C., Léger, F., Lazure, P., 2013. A multi-decadal hindcast of a physical-biogeochemical model and derived oceanographic indices in the Bay of Biscay. J. Mar. Syst. 109-110, S77-S94. doi:10.1016/j.jmarsys.2012.02.009

ICES, 2016. Second Interim report of the Working Group on Acoustic and Egg Surveys for Sardine and Anchovy in ICES Areas VII, VIII and IX (WGACEGG), in: ICES CM 2015/SSGIEOM:31. 16-20 November 2015, Lowestoft, UK., 396 pp.

ICES, 2015. Report of the Working Group on Southern Horse Mackerel, Anchovy and Sardine (WGHANSA). ICES CM 2015/ACOM:16. Lisbon, Portugal.

ICES, 2012. Report of the Workshop on Evaluation of current ecosystem surveys (WKECES). 2022 November 2012, Bergen, Norway. ICES CM 59.

ICES, 2010. Life cycle spatial patterns of small pelagic fish in the Northeast Atlantic. ICES Coop. Res. Rep. 93.

Korneliussen, R.J., Diner, N., Ona, E., Berger, L., Fernandes, P.G., 2008. Proposals for the collection of multifrequency acoustic data. ICES J. Mar. Sci. 65, 982-994. doi:10.1093/icesjms/fsn052

Koutsikopoulos, C., Le Cann, B., 1996. Physical processes and hydrological structures related to the Bay of Biscay anchovy. Sci. Mar. 60, 9-19.

Kupschus, S., Schratzberger, M., Righton, D., 2016. Practical implementation of ecosystem monitoring for the ecosystem approach to management. J. Appl. Ecol. 53, 1236-1247. doi:10.1111/1365-2664.12648

Lambert, C., Authier, M., Doray, M., Dorémus, G., Spitz, J., Ridoux, V., this volume. Ocean temporal heterogeneity impacts the stability of top predators habitat preferences. Prog. Oceanogr.

Lankester, E.R., 1884. The scientific results of the exhibition. Fish. Exhib. Lit. 4, 405-45.

Lasker, R. (Ed.), 1985. An egg production method for estimating spawning biomass of pelagic fish: application to the northern anchovy (Engraulis mordax), U.S. Dep. Commer. ed, NOAA Tech. Rep. NMFS.

Lassalle, G., Gascuel, D., Le Loc'h, F., Lobry, J., Pierce, G.J., Ridoux, V., Santos, M.B., Spitz, J., Niquil, N., 2012. An ecosystem approach for the assessment of fisheries impacts on marine top predators: the Bay of Biscay case study. ICES J. Mar. Sci. 69, 925-938. doi:10.1093/icesjms/fss049

Lassalle, G., Lobry, J., Le Loc’h, F., Bustamante, P., Certain, G., Delmas, D., Dupuy, C., Hily, C., 
Labry, C., Le Pape, O., Marquis, E., Petitgas, P., Pusineri, C., Ridoux, V., Spitz, J., Niquil, N., 2011. Lower trophic levels and detrital biomass control the Bay of Biscay continental shelf food web: Implications for ecosystem management. Prog. Oceanogr. 91, 561-575. doi:10.1016/j.pocean.2011.09.002

Lavery, A.C., Wiebe, P.H., Stanton, T.K., Lawson, G.L., Benfield, M.C., Copley, N., 2007. Determining dominant scatterers of sound in mixed zooplankton populations. J. Acoust. Soc. Am. 122, 3304-3326.

Lazure, P., Garnier, V., Dumas, F., Herry, C., Chifflet, M., 2009. Development of a hydrodynamic model of the Bay of Biscay. Validation of hydrology. Cont. Shelf Res. 29, 985-997. doi:10.1016/j.csr.2008.12.017

Lehodey, P., Conchon, A., Senina, I., Domokos, R., Calmettes, B., Jouanno, J., Hernandez, O., Kloser, R., 2015. Optimization of a micronekton model with acoustic data. ICES J. Mar. Sci. 72, 1399-1412. doi:10.1093/icesjms/fsu233

Lehuta, S., Mahevas, S., Petitgas, P., Pelletier, D., 2010. Combining sensitivity and uncertainty analysis to evaluate the impact of management measures with ISIS-Fish: marine protected areas for the Bay of Biscay anchovy (Engraulis encrasicolus) fishery. ICES J. Mar. Sci. 67, 1063-1075. doi:10.1093/icesjms/fsq002

Lehuta, S., Petitgas, P., Mahévas, S., Huret, M., Vermard, Y., Uriarte, A., Record, N.R., 2013. Selection and validation of a complex fishery model using an uncertainty hierarchy. Fish. Res. 143, 57-66. doi:10.1016/j.fishres.2013.01.008

Lett, C., Ayata, S.-D., Huret, M., Irisson, J.-O., 2010. Biophysical modelling to investigate the effects of climate change on marine population dispersal and connectivity. Prog. Oceanogr. 87, 106-113. doi:10.1016/j.pocean.2010.09.005

Levin, S., 1992. The problem of pattern and scale in ecology. Ecology 73, 1943-1967.

Mahé, J.-C., 1987. EVHOE EVALUATION HALIEUTIQUE DE L'OUEST DE L'EUROPE. http://dx.doi.org/10.18142/8

Mair, A., Fernandes, P., Lebourges-Dhaussy, A., Brierley, A., 2005. An investigation into the zooplankton composition of a prominent $38-\mathrm{kHz}$ scattering layer in the North Sea. J Plankton Res 27, 623-633.

Marquis, E., Niquil, N., Delmas, D., Hartmann, H.J., Bonnet, D., Carlotti, F., Herbland, A., Labry, C., Sautour, B., Laborde, P., Vézina, A., Dupuy, C., 2007. Inverse analysis of the planktonic food web dynamics related to phytoplankton bloom development on the continental shelf of the Bay of Biscay, French coast. Estuar. Coast. Shelf Sci. 73, 223-235. doi:10.1016/j.ecss.2007.01.003

Marquis, E., Niquil, N., Vezina, A.F., Petitgas, P., Dupuy, C., 2011. Influence of planktonic foodweb structure on a system's capacity to support pelagic production: an inverse analysis approach. ICES J. Mar. Sci. 68, 803-812. doi:10.1093/icesjms/fsr027

Massé, J., Retière, N., 1995. Effect of number of transects and identification hauls on acoustic biomass estimates under mixed species conditions. Aquat. Living Resour. 8, 195-199. doi:10.1051/alr:1995017

Massé, J., Sanchez, F., Delaunay, D., Robert, J.M., Petitgas, P., 2016. A partnership between science and industry for a monitoring of anchovy and sardine in the Bay of Biscay: When fishermen are actors of science. Fish. Res. 178, 26-38. doi:10.1016/j.fishres.2015.11.018

Massé, J., Uriarte, A., Angelico, M.M., Carrera, P., In press. Pelagic survey series for sardine and anchovy in ICES subareas 8 and 9 (WGACEGG) - Towards an ecosystem approach. ICES Coop. Res. Rep. 332.

OSPAR Commission, 2000. Quality Status Report 2000: Region IV e Bay of Biscay and Iberian. OSPAR Commission report.

Pecquerie, L., Petitgas, P., Kooijman, S.A.L.M., 2009. Modeling fish growth and reproduction in the context of the Dynamic Energy Budget theory to predict environmental impact on 
anchovy spawning duration. J. Sea Res. 62, 93-105. doi:10.1016/j.seares.2009.06.002

Perrot, L., Lampert, L., Ruiz-Pino, D., Gohin, F., Dessier, A., Bourriau, P., this volume. Spatial and vertical variability of coccolithophore blooms in the Bay of Biscay by satellite SPM and in situ turbidity from PELGAS cruises. Prog. Oceanogr.

Petersen, W., 2014. FerryBox systems: State-of-the-art in Europe and future development. J. Mar. Syst. 140, 4-12. doi:10.1016/j.jmarsys.2014.07.003

Petitgas, P., 2003. A method for the identification and characterization of clusters of schools along the transect lines of fisheries-acoustic surveys. ICES J Mar Sci 60, 872-884.

Petitgas, P., Alheit, J., Peck, M., Raab, K., Irigoien, X., Huret, M., van der Kooij, J., Pohlmann, T., Wagner, C., Zarraonaindia, I., Dickey-Collas, M., 2012. Anchovy population expansion in the North Sea. Mar. Ecol. Prog. Ser. 444, 1-13. doi:10.3354/meps09451

Petitgas, P., Doray, M., Huret, M., Massé, J., Woillez, M., 2014. Modelling the variability in fish spatial distributions over time with empirical orthogonal functions: anchovy in the Bay of Biscay. ICES J. Mar. Sci. 71, 2379-2389. doi:10.1093/icesjms/fsu111

Petitgas, P., Doray, M., Massé, J., Grellier, P., 2011. Spatially explicit estimation of fish length histograms, with application to anchovy habitats in the Bay of Biscay. ICES J. Mar. Sci. J. Cons. doi:10.1093/icesjms/fsr139

Petitgas, P., Goarant, A., Massé, J., Bourriau, P., 2009. Combining acoustic and CUFES data for the quality control of fish-stock survey estimates. ICES J Mar Sci 66, 1384-1390.

Petitgas, P., Huret, M., Dupuy, C., Spitz, J., Authier, M., Romagnan, J.B., Doray, M., this volume. Ecosystem spatial structure revealed by integrated survey data. Prog. Oceanogr.

Petitgas, P., Massé, J., Beillois, P., Lebarbier, E., Le Cann, A., 2003. Sampling variance of species identification in fisheries-acoustic surveys based on automated procedures associating acoustic images and trawl hauls. ICES J Mar Sci 60, 437-445.

Petitgas, P., Massé, J., Bourriau, P., Beillois, P., Delmas, D., Herbland, A., Koueta, N., Froidefond, J., Santos, M., 2006. Hydro-plankton characteristics and their relationship with sardine and anchovy distributions on the French shelf of the Bay of Biscay. Sci Mar 70S1, 161-172.

Picheral, M., Colin, S., Irisson, J.-O., 2016. EcoTaxa, a tool for the taxonomic classification of images. http://ecotaxa.obs-vlfr.fr

Planque, B., Bellier, E., Lazure, P., 2007. Modelling potential spawning habitat of sardine (Sardina pilchardus) and anchovy (Engraulis encrasicolus) in the Bay of Biscay. Fish Ocean. 16, 1630.

Planque, B., Lazure, P., Jegou, A., 2006. Typology of hydrological structures modelled and observed over the Bay of Biscay shelf. Sci. Mar. 70S1, 43-50.

Politikos, D.V., Huret, M., Petitgas, P., 2015. A coupled movement and bioenergetics model to explore the spawning migration of anchovy in the Bay of Biscay. Ecol. Model. 313, 212222. doi:10.1016/j.ecolmodel.2015.06.036

Poulard, J., Blanchard, F., 2005. The impact of climate change on the fish community structure of the eastern continental shelf of the Bay of Biscay. ICES J. Mar. Sci. 62, 1436-1443. doi:10.1016/j.icesjms.2005.04.017

Renfree, J.S., Demer, D.A., 2016. Optimizing transmit interval and logging range while avoiding aliased seabed echoes. ICES J. Mar. Sci. J. Cons. 73, 1955-1964. doi:10.1093/icesjms/fsw055

Reverdin, G., Marié, L., Lazure, P., d’Ovidio, F., Boutin, J., Testor, P., Martin, N., Lourenco, A., Gaillard, F., Lavin, A., Rodriguez, C., Somavilla, R., Mader, J., Rubio, A., Blouch, P., Rolland, J., Bozec, Y., Charria, G., Batifoulier, F., Dumas, F., Louazel, S., Chanut, J., 2013. Freshwater from the Bay of Biscay shelves in 2009. J. Mar. Syst. 109-110, S134-S143. doi:10.1016/j.jmarsys.2011.09.017

Richardson, A., 2008. In hot water: zooplankton and climate change. ICES J Mar Sci 65, 279-295.

Shephard, S., van Hal, R., de Boois, I., Birchenough, S.N.R., Foden, J., O’Connor, J., Geelhoed, 
S.C.V., Van Hoey, G., Marco-Rius, F., Reid, D.G., Schaber, M., 2015. Making progress towards integration of existing sampling activities to establish Joint Monitoring Programmes in support of the MSFD. Mar. Policy 59, 105-111. doi:10.1016/j.marpol.2015.06.004

Simmonds, E.J., MacLennan, D.N., 2005. Fisheries Acoustics. Theory and Practice. Blackwell publishing, Oxford, UK.

Spitz, J., Jouma'a, J., 2013. Variability in energy density of forage fishes from the Bay of Biscay (north-east Atlantic Ocean): reliability of functional grouping based on prey quality: variability in energy density of forage fishes. J. Fish Biol. 82, 2147-2152. doi:10.1111/jfb.12142

Spitz, J., Mourocq, E., Schoen, V., Ridoux, V., 2010. Proximate composition and energy content of forage species from the Bay of Biscay: high- or low-quality food? ICES J. Mar. Sci. 67, 909-915.

Spitz, J., Ridoux, V., Trites, A.W., Laran, S., Authier, M., this volume. Prey consumption by cetaceans reveals the importance of energy-rich food webs in the Bay of Biscay. Prog. Oceanogr. doi:10.1016/j.pocean.2017.09.013

Stanton, T.K., Chu, D.Z., Jech, J.M., Irish, J.D., 2010. New broadband methods for resonance classification and high-resolution imagery of fish with swimbladders using a modified commercial broadband echosounder. ICES J Mar Sci 67, 365-378.

Stanton, T.K., Sellers, C.J., Jech, J.M., 2012. Resonance classification of mixed assemblages of fish with swimbladders using a modified commercial broadband acoustic echosounder at 16 kHz. Can. J. Fish. Aquat. Sci. 69, 854-868. doi:10.1139/f2012-013

Trenkel, V., Mazauric, V., Berger, L., 2008. The new fisheries multibeam echosounder ME70: description and expected contribution to fisheries research. ICES J Mar Sci 65, 645-655.

Trenkel, V.M., Berger, L., Bourguignon, S., Doray, M., Fablet, R., Massé, J., Mazauric, V., Poncelet, C., Quemener, G., Scalabrin, C., Villalobos, H., 2009. Overview of recent progress in fisheries acoustics made by Ifremer with examples from the Bay of Biscay. Aquat Living Res 22.

Vandromme, P., Nogueira, E., Huret, M., Lopez-Urrutia, Á., González-Nuevo González, G., Sourisseau, M., Petitgas, P., 2014. Springtime zooplankton size structure over the continental shelf of the Bay of Biscay. Ocean Sci 10, 821-835. doi:10.5194/os-10-821-2014

Vérin, Y., 1992. IBTS INTERNATIONAL BOTTOM TRAWL SURVEY (IBTS). http://dx.doi.org/10.18142/17

Weill, A., Scalabrin, C., Diner, N., 1993. MOVIES-B: An acoustic detection description software. Application to shoal species' classification. Aquat Living Resour 6, 255-267.

Woillez, M., Poulard, J.C., Rivoirard, J., Petitgas, P., Bez, N., 2007. Indices for capturing spatial patterns and their evolution in time, with application to European hake (Merluccius merluccius) in the Bay of Biscay. ICES J Mar Sci 64, 537-550.

Zwolinski, J.P., Demer, D.A., Cutter Jr., G.R., Stierhoff, K., Macewicz, B.J., 2014. Building on Fisheries Acoustics for Marine Ecosystem Surveys. Oceanography 27, 68-79.

\section{Annex 1: Acronym Glossary}

ATLANTOS: “Atlantic Ocean Observing System” European Union’s Horizon 2020 research and innovation programme project (2015-2019, Project no. 633211)

CDOM: Coloured Dissolved Organic Matter concentration

CLUSTER: "Aggregation patterns of pelagic commercial fish under different stock situations and their 
impact on exploitation and assessment” European project (1996-1998, FAIR CT96-1799).

CTD: Conductivity-Temperature-Depth sonde

CUFES: Continuous Underway Fish Egg Sampler

DCF: European Common Fisheries Policy Data Collection Framework

DCM: Deep Chlorophyll Maximum

DEPM: Daily Egg Production Method

EAF: Ecosystem Approach to Fisheries

EVHOE: "Evaluation Halieutique de l'Ouest de L'Europe" bottom trawl survey

FACTS: "Forage Fish Interactions" European Commission's Seventh Framework Programme small project (2010-2012, Project no. 244966)

GES: Good Ecological Status

IBTS: International Bottom Trawl Survey

ICES: International Council for the Exploration of the Sea

JUVENA: acoustic surveying of anchovy Juveniles in the Bay of Biscay

LOPC: Laser Optical Particle Counter

MSFD: European Marine Strategy Framework Directive

NM: nautical mile (1852 m)

PELACUS: Multidisciplinary acoustic-trawl survey

PELAGO: Spring Acoustics Survey in Atlantic Iberian waters of ICES area 9a (Cabo Trafalgar to River Minho)

PELASSES, "Direct abundance estimation and distribution of pelagic fish species in North East Atlantic waters" European project. (2000-2002, DGXIV n 99.010)

PELGAS: "Pélagiques Gascogne” integrated survey

PELTIC: Pelagic ecosystem survey in western Channel and eastern Celtic Sea

RECLAIM: "REsolving CLimAtic IMpacts on fish stocks" European Commission's Sixth Framework Programme project (2006-2010, Project no. 044133 (SSP8)) 
REPRODUCE: "Understanding REcruitment PROcesses Using Coupled biophysical models of the pelagic Ecosystem” European Commission's Seventh Framework Programme MariFish EraNet's project (20102012)

SEAMAN: "Spatially resolved Ecosystem models and their Application to Marine MANagement" European Commission's Seventh Framework Programme SeaSera EraNet's project (2013-2015)

UNCOVER: "Understanding the Mechanisms of Stock Recovery" European Commission's Sixth Framework Programme project (2006-2010, Project no. 022717 (SSP 8))

WGACEGG: ICES Working Group on Acoustic and Egg Surveys for Sardine and Anchovy in ICES areas VII, VIII and IX

WGHANSA: ICES Working Group on Southern Horse Mackerel, Anchovy, and Sardine

WP2: UNESCO Working Party 2 mesozooplankton netSIMFAMI: "Species Identification Methods From Acoustic Multi-frequency Information" European Commission's Fifth Framework Programme project (2001-2005, Q5RS-2001-02054) 


\section{Figures}

Figure 1.

PELGAS

survey

scheme.

systematic

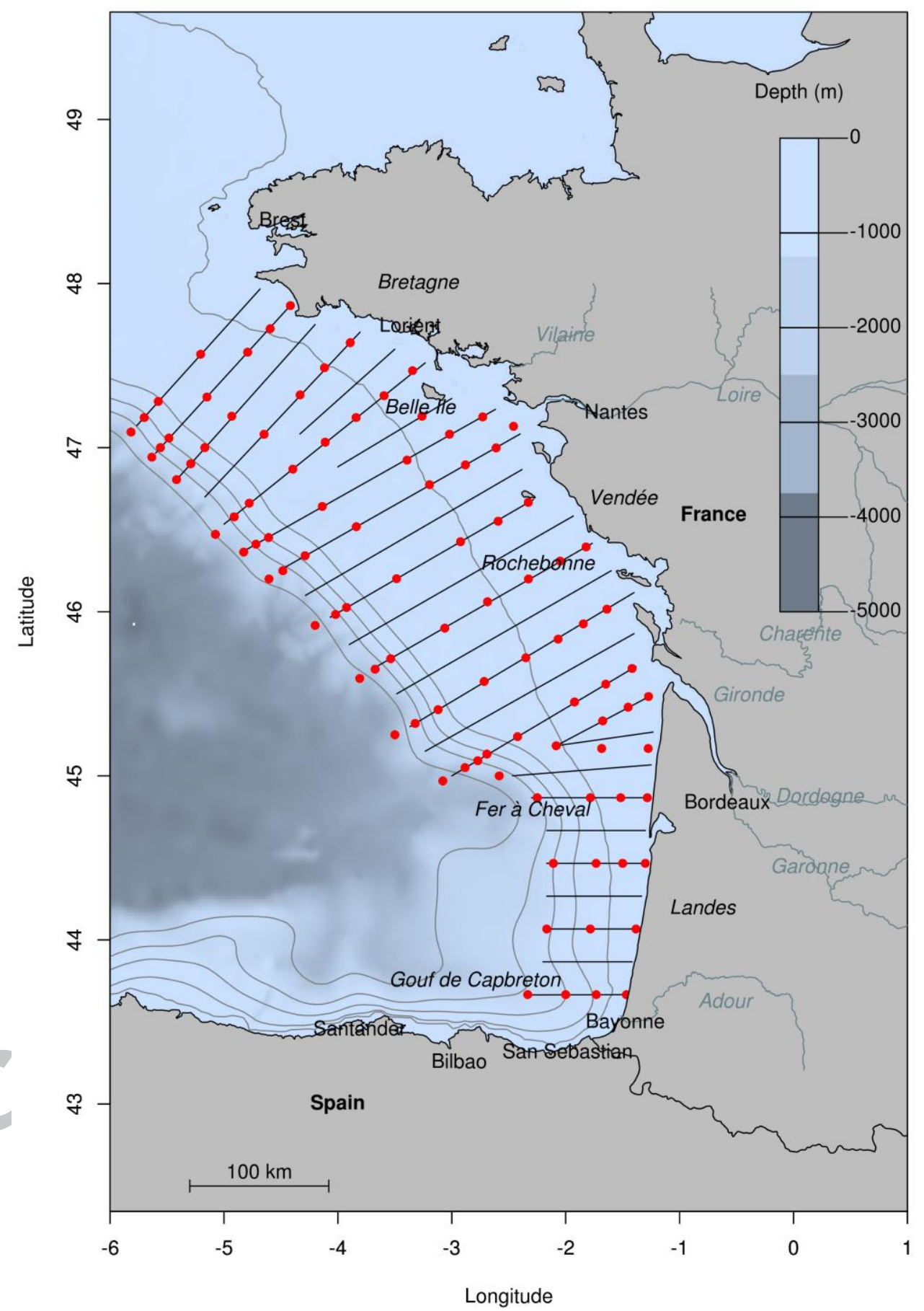

sampling

Solid lines:

line

transects,

red dots:

hydrobiology stations. Light grey lines: $100,200,300,400,500 \mathrm{~m}$ isobaths. 

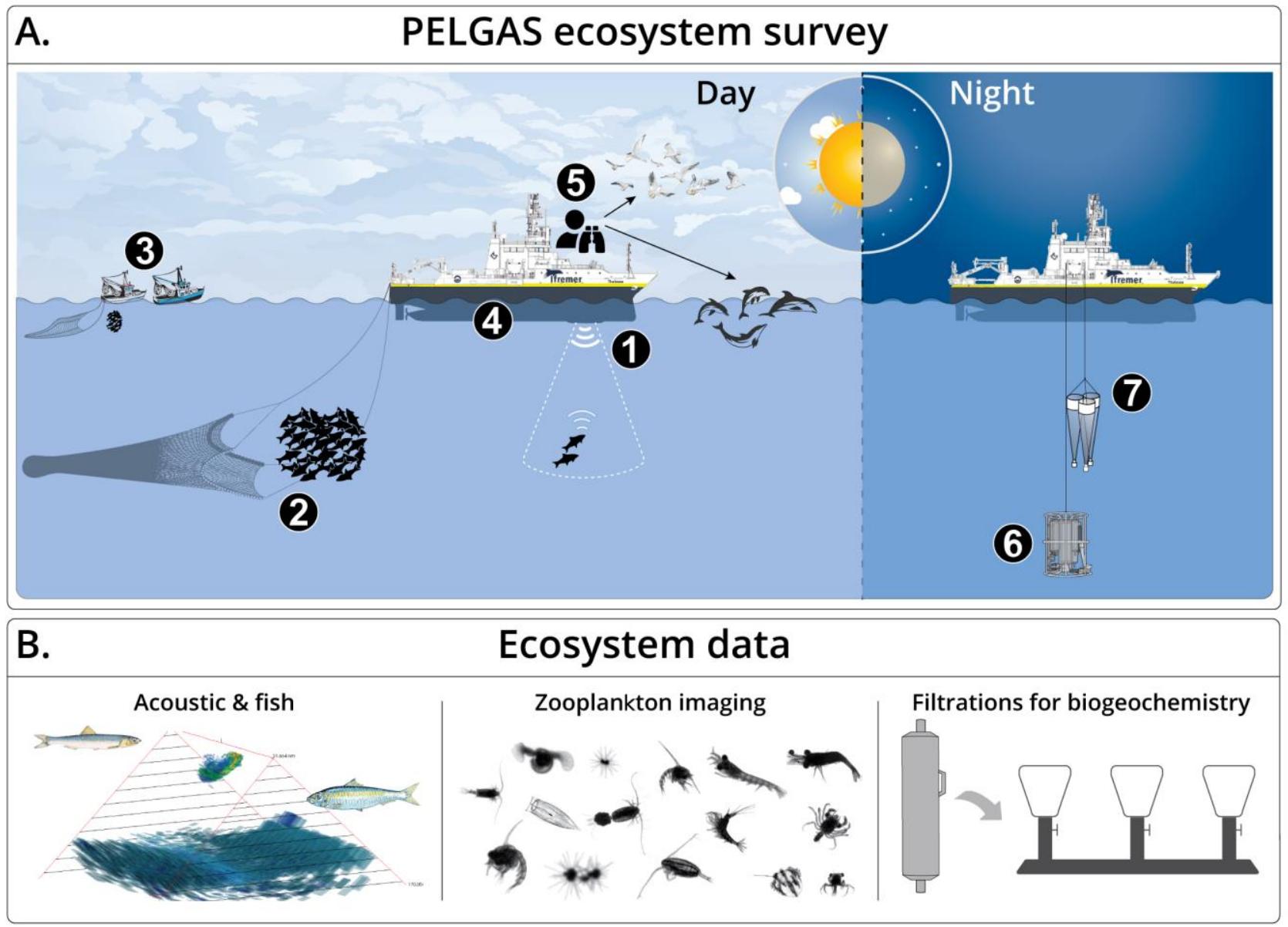

\section{C. $\quad$ Ecosystem survey products}
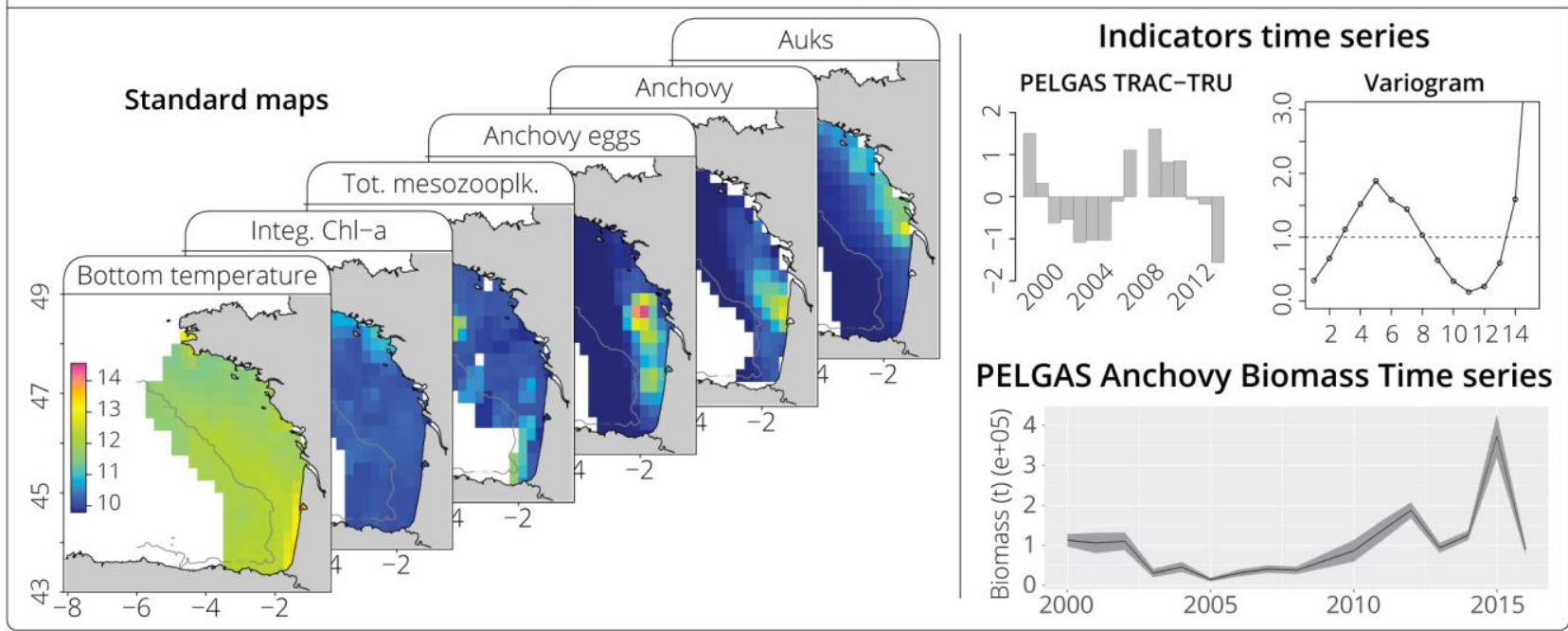

Figure 2. The PELGAS survey model. A. Ecosystem data collection in spring in the Bay of Biscay. During daytime, along line transects: 1. Fisheries acoustics, 2. R/V Thalassa midwater trawling, 3. Consort commercial pair trawlers fishing, 4. Hull-mounted thermosalinometer, 5. Megafauna sightings. During nighttime, at fixed stations: 6. Sonde-based hydrobiological sampling, 7. Meso-zooplankton nets. B. Onboard ecosystem data pre-processing: acoustic data scrutinising, midwater trawl catch sorting, biological 
parameters recording, zoo and ichthyology-plankton imaging, seawater filtrations for biogeochemistry. C. Ecosystem products: standard raster maps of parameters in all pelagic ecosystem components, time series of indicators of the state of Biscay pelagic ecosystem, including commercial fish stocks. 

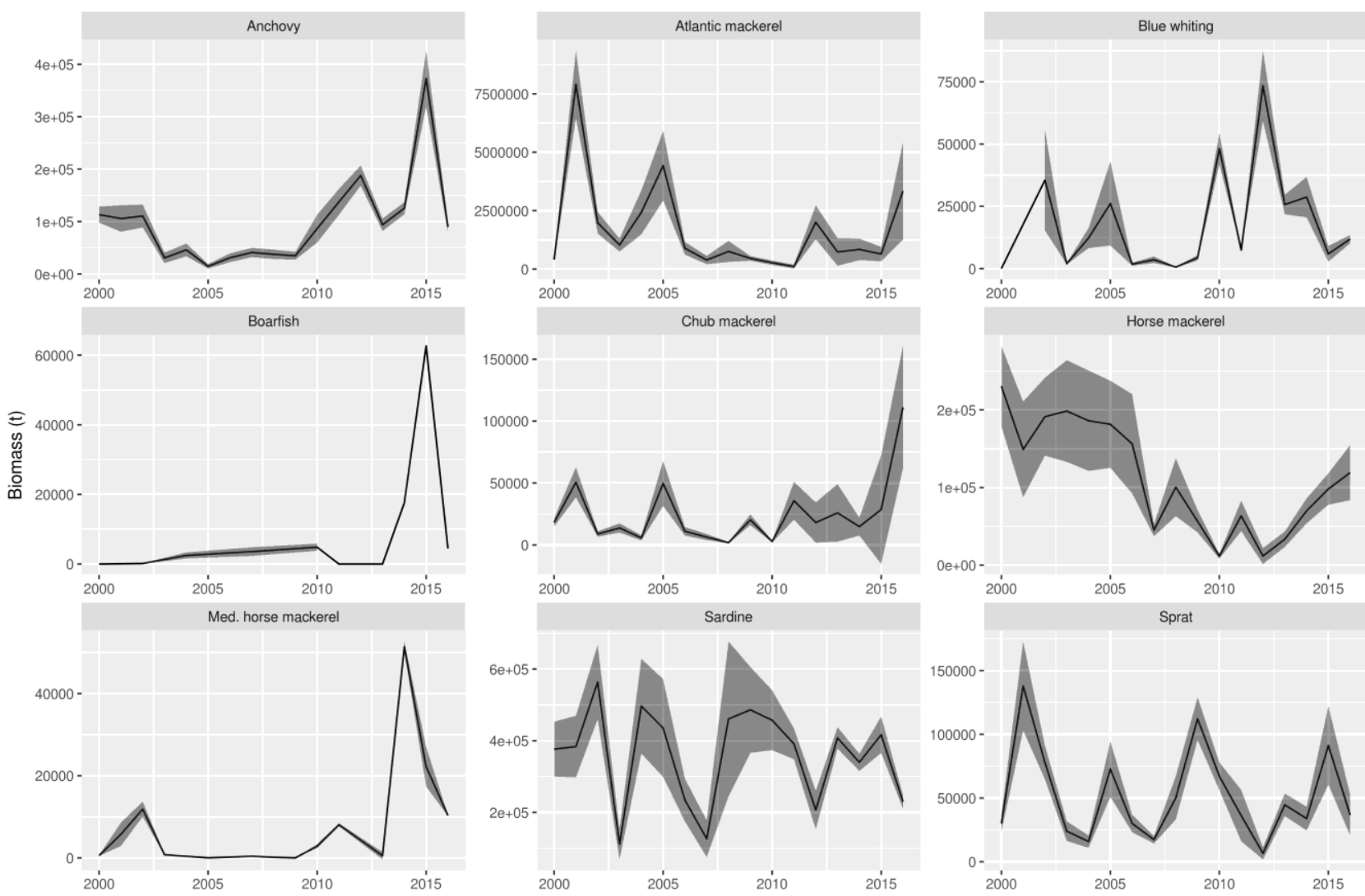

Figure 3. Small pelagic biomass estimates series (in metric tons) derived from the PELGAS survey acoustic and trawl data: anchovy, Engraulis encrasicolus, Atlantic mackerel, Scomber scombrus; blue whiting, Micromesistius poutassou; boarfish, Capros aper; Atlantic chub mackerel, Scomber colias; horse mackerel, Trachurus trachurus; Mediterranean horse mackerel, Trachurus mediterraneus; ; sardine, Sardina pilchardus; sprat, Sprattus sprattus. 


\section{Tables}

Table 1. Time line of standardised data collection evolutions and supplementary process studies conducted during or in conjunction with the PELGAS surveys.

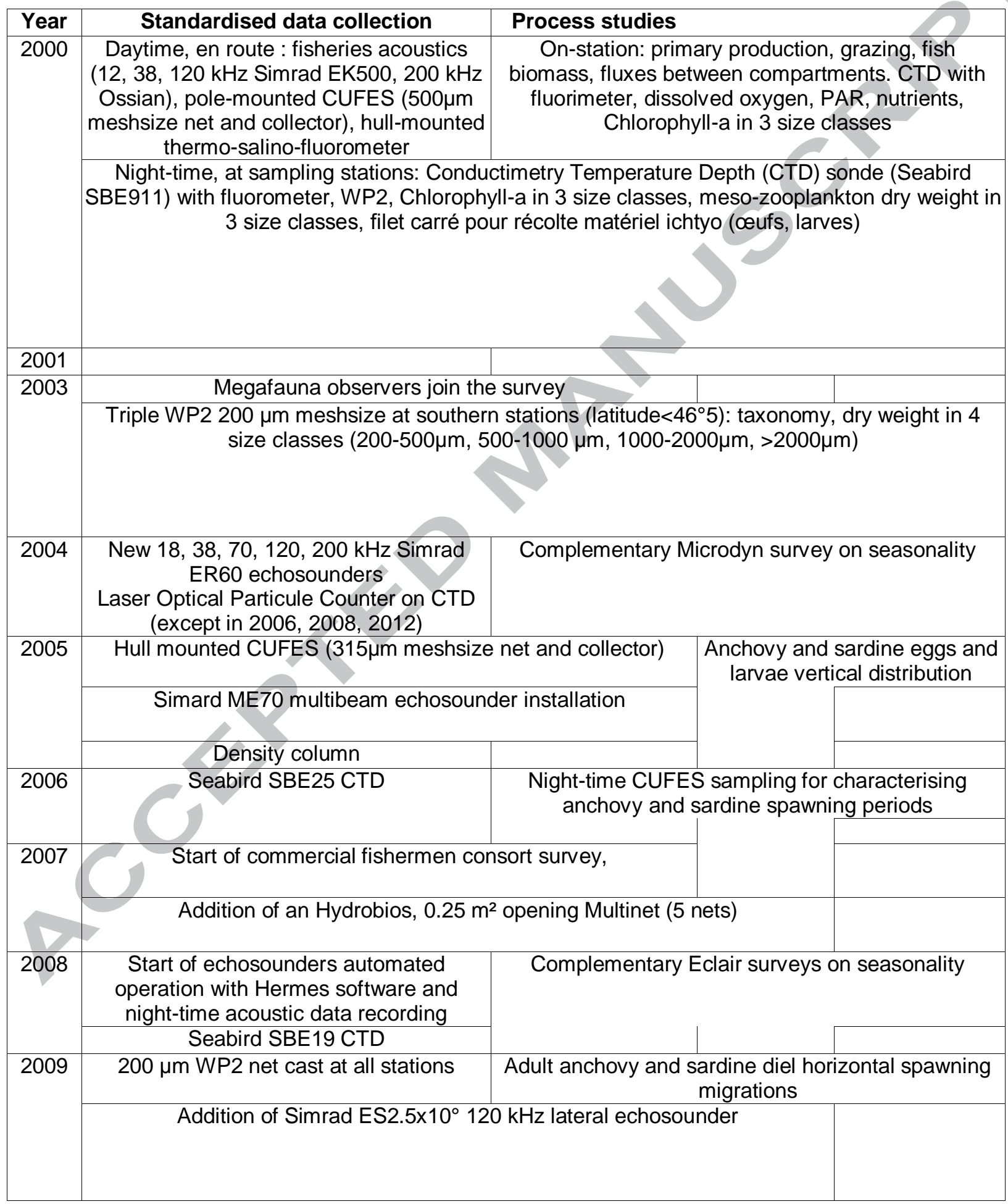




\begin{tabular}{|c|c|c|c|}
\hline 2010 & & $\begin{array}{l}\text { Anchovy and sardine qualitative } \\
\text { stomach contents analysis }\end{array}$ & $\begin{array}{l}\text { Sound scattering } \\
\text { layers } \\
\text { characterisation }\end{array}$ \\
\hline 2011 & & \multicolumn{2}{|c|}{$\begin{array}{c}\text { Anchovy and sardine individual acoustic backscatter } \\
\text { measurements }\end{array}$} \\
\hline 2012 & \multicolumn{2}{|c|}{ Addition of $333 \mathrm{kHz}$ Simrad ER60 echosounder } & \\
\hline & \multicolumn{2}{|c|}{ Addition of turbidimeter on CTD sonde, start of nutrients analysis } & \\
\hline 2013 & & \multirow{2}{*}{\multicolumn{2}{|c|}{$\begin{array}{c}\text { Anchovy and sardine individual acoustic backscatter } \\
\text { measurements }\end{array}$}} \\
\hline 2014 & Start of ZooCAM routine use & & \\
\hline 2015 & \multicolumn{2}{|c|}{ Addition of dissolved oxygen sensor on CTD sonde } & \multirow{3}{*}{$\begin{array}{l}\text { Sound scattering } \\
\quad \text { layers } \\
\text { characterisation }\end{array}$} \\
\hline 2016 & $\begin{array}{l}\text { Start of gelatinous plankton analysis in } \\
\text { trawl catches }\end{array}$ & $\begin{array}{l}\text { Anchovy and sardine qualitative } \\
\text { stomach contents analysis }\end{array}$ & \\
\hline 2017 & \multicolumn{2}{|c|}{ Addition of $\mathrm{pH}$-meter on CTD sonde } & \\
\hline
\end{tabular}

Table 2. Potential indicators of the state of the Bay of Biscay pelagic ecosystem derived from the PELGAS survey. Mesozooplankton and small pelagic fish indicators can be provided for all species, or per species and/or size. Cetaceans and seabirds indicators can be provided for all species, or per species or group of species. Distributional pattern indicators are computed based on Woillez et al. (2007).

\begin{tabular}{|c|c|c|c|c|}
\hline Descriptor & Attribute & Criteria & \multicolumn{2}{|c|}{ Indicators } \\
\hline \multirow[t]{16}{*}{ Biodiversity } & \multirow{15}{*}{$\begin{array}{c}\text { Species: } \\
\text { zooplankton } \\
(>20 \mu \mathrm{mm}, 2006- \\
2016), \text { small } \\
\text { pelagic fish } \\
\text { (adults and } \\
\text { eggs, 2000- } \\
2016), \\
\text { cetaceans } \\
\text { (adults, 2003- } \\
2016), \\
\text { seabirds } \\
\text { (adults, 2003- } \\
2016) \text {. }\end{array}$} & $\begin{array}{l}\text { Population } \\
\text { size }\end{array}$ & & $\begin{array}{l}\text { Acoustic total } \\
\text { biomass\&abundance } \\
\text { estimates, along with } \\
\text { estimation error }\end{array}$ \\
\hline & & $\begin{array}{l}\text { Population } \\
\text { condition }\end{array}$ & & $\begin{array}{l}\text { Acoustic } \\
\text { biomass\&abundance } \\
\text { estimates per } \\
\text { size/age }\end{array}$ \\
\hline & & \multirow[t]{13}{*}{$\begin{array}{c}\text { Species } \\
\text { distribution }\end{array}$} & $\begin{array}{l}\text { Distributional } \\
\text { range }\end{array}$ & Surface area \\
\hline & & & \multirow{12}{*}{$\begin{array}{c}\text { Distributional } \\
\text { pattern (survey } \\
\text { scale) }\end{array}$} & Centre of gravity \\
\hline & & & & Spatial patches \\
\hline & & & & Inertia \\
\hline & & & & Isotropy \\
\hline & & & & Positive area \\
\hline & & & & Spreading area \\
\hline & & & & Equivalent area \\
\hline & & & & Gini index \\
\hline & & & & $\begin{array}{l}\text { Coefficient of variation } \\
\text { of strictly positive } \\
\text { densities }\end{array}$ \\
\hline & & & & Microstructure \\
\hline & & & & Mean biomass \\
\hline & & & & $\begin{array}{l}\text { Percentage of total } \\
\text { area occupied }\end{array}$ \\
\hline & Community & Community & & Total pelagic fish \\
\hline
\end{tabular}




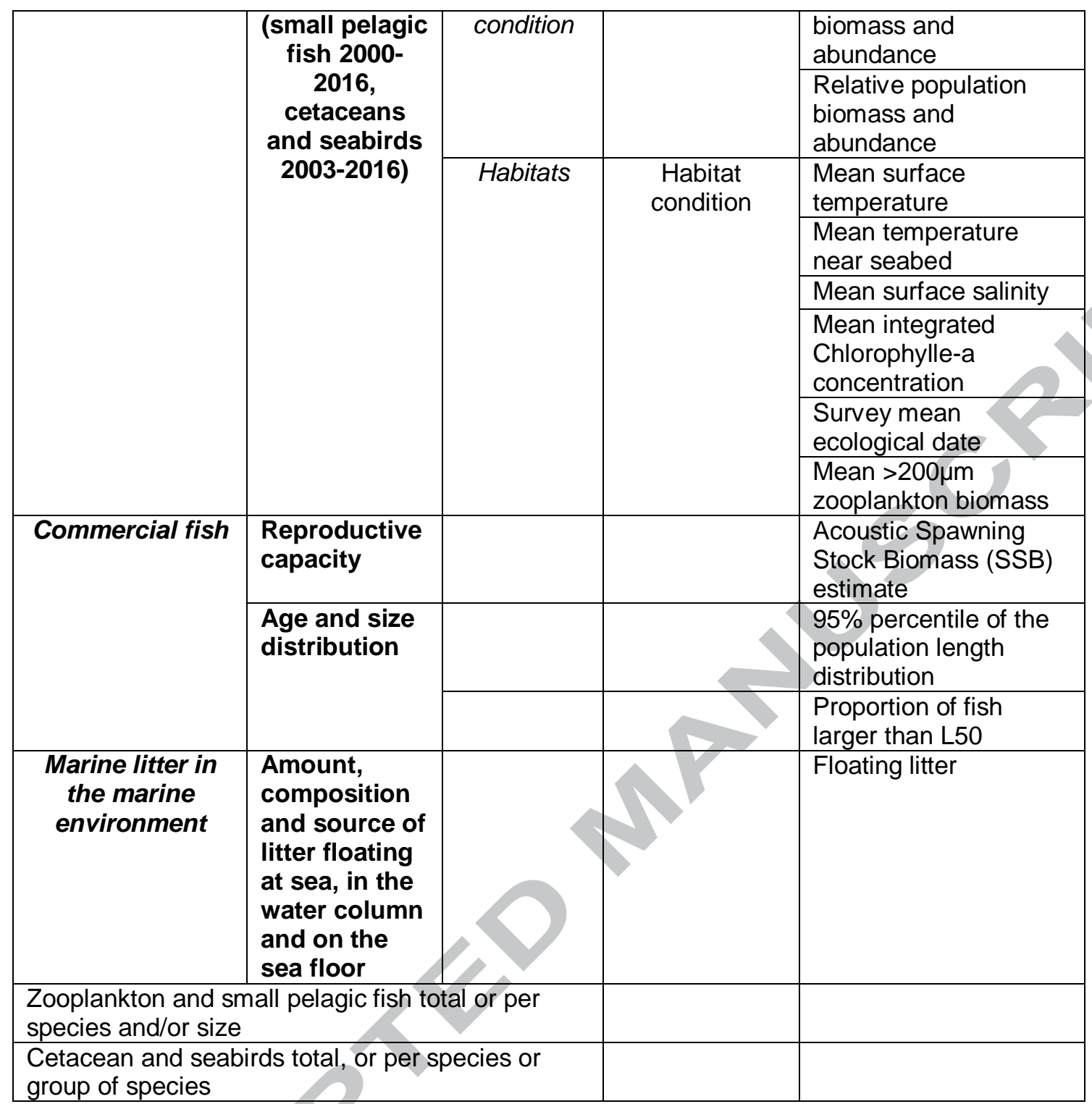

